Article

\title{
Evaluation of Environmental Quality of Mediterranean Coastal Lagoons Using Persistent Organic Pollutants and Metals in Thick-Lipped Grey Mullet
}

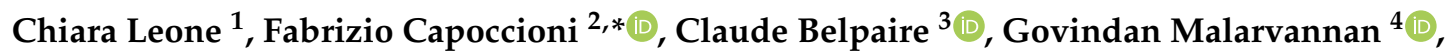 \\ Giulia Poma ${ }^{4}{ }^{\infty}$, Adrian Covaci ${ }^{4}\left(\mathbb{D}\right.$, Lorenzo Tancioni ${ }^{1}$, Michela Contò ${ }^{2}$ and Eleonora Ciccotti ${ }^{1}$ \\ 1 Dipartimento di Biologia-Università degli Studi di Roma “Tor Vergata", 00133 Rome, Italy; \\ chiara.leone@uniroma2.it (C.L.); tancioni@uniroma2.it (L.T.); ciccotti@uniroma2.it (E.C.) \\ 2 Centro di Ricerca "Zootecnia e Acquacoltura"-Consiglio per la Ricerca in Agricoltura e l'Analisi \\ dell'Economia Agraria (CREA), 00015 Monterotondo (Rm), Italy; michela.conto@crea.gov.it \\ 3 Institute for Nature and Forest Research (INBO), Dwersbos, 1630 Linkebeek, Belgium; \\ claude.belpaire@inbo.be \\ 4 Toxicological Centre, University of Antwerp, 2610 Wilrijk, Belgium; \\ malarvannan.govindan@uantwerpen.be (G.M.); giulia.poma@uantwerpen.be (G.P.); \\ adrian.covaci@uantwerpen.be (A.C.) \\ * Correspondence: fabrizio.capoccioni@crea.gov.it; Tel.: +39-06-90090-263
}

Received: 23 November 2020; Accepted: 7 December 2020; Published: 8 December 2020

\begin{abstract}
The evaluation of past and present anthropogenic impacts affecting the ecological quality status of transitional ecosystems is crucial from the perspective of protecting them from further deterioration, and to evaluate remediation and restoration measures. Contamination patterns of thick-lipped grey mullet from two Mediterranean coastal lagoons within a protected area in Italy were assessed and compared in order to evaluate their overall quality status and to collect information that can provide useful feedback on management choices aimed at enhancing environmental quality and biodiversity conservation. The quality status of the two lagoons was evaluated by an environmental assessment methodology based on indicators of direct and indirect human pressures, while a broad range of analyses were carried out to determine the presence and concentration of persistent organic pollutants (POPs) and metals in fish muscle tissue. A good quality status resulted for both lagoons, and an overall limited anthropogenic impact in the surrounding area. This could account for POPs and metal contamination levels found in mullet, although limited, and relating to their patterns. The overlap of results achieved with the two evaluation approaches can provide support for management choices in Mediterranean lagoon environments, especially for those committed to the protection and conservation of biodiversity.
\end{abstract}

Keywords: POPs; metals; lagoon ecosystem; bioindicator; Chelon labrosus; Italy; environmental quality

\section{Introduction}

Coastal lagoons are shallow aquatic environments which span from freshwater to hypersaline conditions depending on the water balance [1,2], and that show significant ecological gradients due to their intermediate position between the continental and marine domain. They support a high biodiversity of habitats suitable for birds, fish and invertebrate species [3], many of which are commercially or recreationally harvested all over the world, namely in the Mediterranean region [4-6]. The exploitation of living resources in these highly resilient and productive ecosystems has been 
providing livelihood to humans since ancient times [3,6,7]. Other valuable ecosystem services [8-11], such as shore protection by coastal erosion, harbor and navigation facilities, flood control, waste and pollution assimilation, are also provided by coastal lagoons, related to their strategic position in the coastal area as well as to their ecological features [12,13].

Several threats are increasingly affecting lagoons as a direct consequence of the multiple uses of inland and coastal aquatic ecosystems, relating to habitat degradation and loss. These have been progressively occurring in most coastal lagoons, in the Mediterranean and elsewhere, as a consequence of the additive effects of many anthropogenic impacts [14]. Among these, water pollution due to the input of persistent organic pollutants (POPs) and toxic metals, as well as land use and reclamation, overexploitation of resources, introduction and spread of invasive species are the most relevant $[7,13,15]$. This has raised concerns for the ability of coastal lagoons and wetlands to further support the provision of valuable ecosystem services $[10,14,16]$. Therefore, the need to evaluate anthropogenic impacts affecting the overall status and quality of transitional ecosystems has become imperative from the perspective of protecting them from further deterioration, and to evaluate remediation and restoration measures.

The use of fish as a bioindicator for the evaluation of the environmental status of aquatic ecosystems and to assess habitat alterations is an issue that was raised long ago, and there are many reasons why fish are widely used [17]. The inclusion of fish as a Biological Quality Element (BQE) in the implementation of the Water Framework Directive (WFD) 2000/60 [18] has added further interest, especially for transitional waters [19-22]. The proposed methods for the assessment of the ecological status of transitional waters, based on fish as BQE, rely on the use of multi-metric indices that take into account the fish assemblage of the lagoon as a whole, and supplementary information to evaluate anthropogenic pressures acting on the lagoon $[23,24]$. Nevertheless, the approach based on the use of a single fish species as a biological indicator remains valid [25], and can rely on the use of fish condition, health and contamination patterns. With reference to the latter, long-living organisms such as fish are sensitive to complex mixtures of chemicals in specific ecosystems, and therefore tissue concentrations of chemicals are indicators of the environmental loads of specific toxicants, also integrating the information over time and space. Many pollutants may persist for decades and accumulate in soils and sediments, from which they can be remobilized because of the changing physico-chemical condition of the water body, or management interventions directly involving bottom and sediments. Hence, fish contamination can integrate information on changes occurring over time and space in environmental conditions and the status of a wide variety of aquatic ecosystems [19,26-29].

Among the potential environmental indicators or sentinel species for such ecosystems, many mullet species have been taken into account [30-33]. Grey mullets (Mugilidae) are one of the most ubiquitous teleost families in transitional and coastal waters [34], with five species dwelling in coastal lagoons in the Mediterranean region, and one of these is the thick-lipped grey mullet, Chelon labrosus (R. 1827). This marine migrant species enters lagoons at the juvenile stage, during which it displays a planktonic diet, and dwells in these environments in the adult phase, mainly with detritivorous habits [32-35], ingesting large amounts of the sediment organic matter (detritus, benthic diatoms and algae, small invertebrates, and crustaceans). After a growth period of variable duration (2-3 years males and 3-4 years females), adults return to marine coastal waters between December and February for spawning [34]. The life cycle then takes place mostly in transitional waters, and the feeding behavior, both as detritivore and water-column filter-feeder, makes C. labrosus potentially interesting as a biological indicator of chemical contamination since it can integrate possible contamination of both water and sediment matrices [33].

In this study, contamination patterns in the thick-lipped grey mullet from two Mediterranean coastal lagoons are evaluated, based on concentrations of a broad range of organochlorine compounds and metals analyzed in fish muscle tissue. Along with this, an assessment of the environmental quality status of the two lagoons is performed, based on descriptors of direct and indirect human pressures acting on these lagoon ecosystems. The aim is to assess the environmental quality of the lagoons, and to compare the results obtained with the two study approaches, in order to evaluate 
if the use of the thick-lipped grey as bioindicator can give feedback useful to direct management choices for safeguarding habitat environmental quality, from the perspective of supporting biodiversity conservation in Mediterranean coastal lagoons.

\section{Materials and Methods}

\subsection{Study Sites}

The coastal lagoons of Fogliano and Caprolace are included within the Circeo National Park (Figure 1), that addresses species and habitats conservation, fisheries in the lagoons being banned since 2007, and carries on the environmental management of the lagoons in collaboration with the Forestry Unit of the Carabinieri Force. Their main ecological features are given in Table 1. Each lagoon is connected to the sea by a tidal channel, occasionally dredged to maintain water exchanges when silting occurs. Freshwater supplies (provided originally to Fogliano by a river and Caprolace by some adjacent channels) were cut off during the 80 s because of their poor water quality, which frequently led to water eutrophication [36]. The whole area lies within a reclamation plain [37], and land use is directed mainly at intensive agriculture and livestock, while industrial activities are reduced in the whole area.

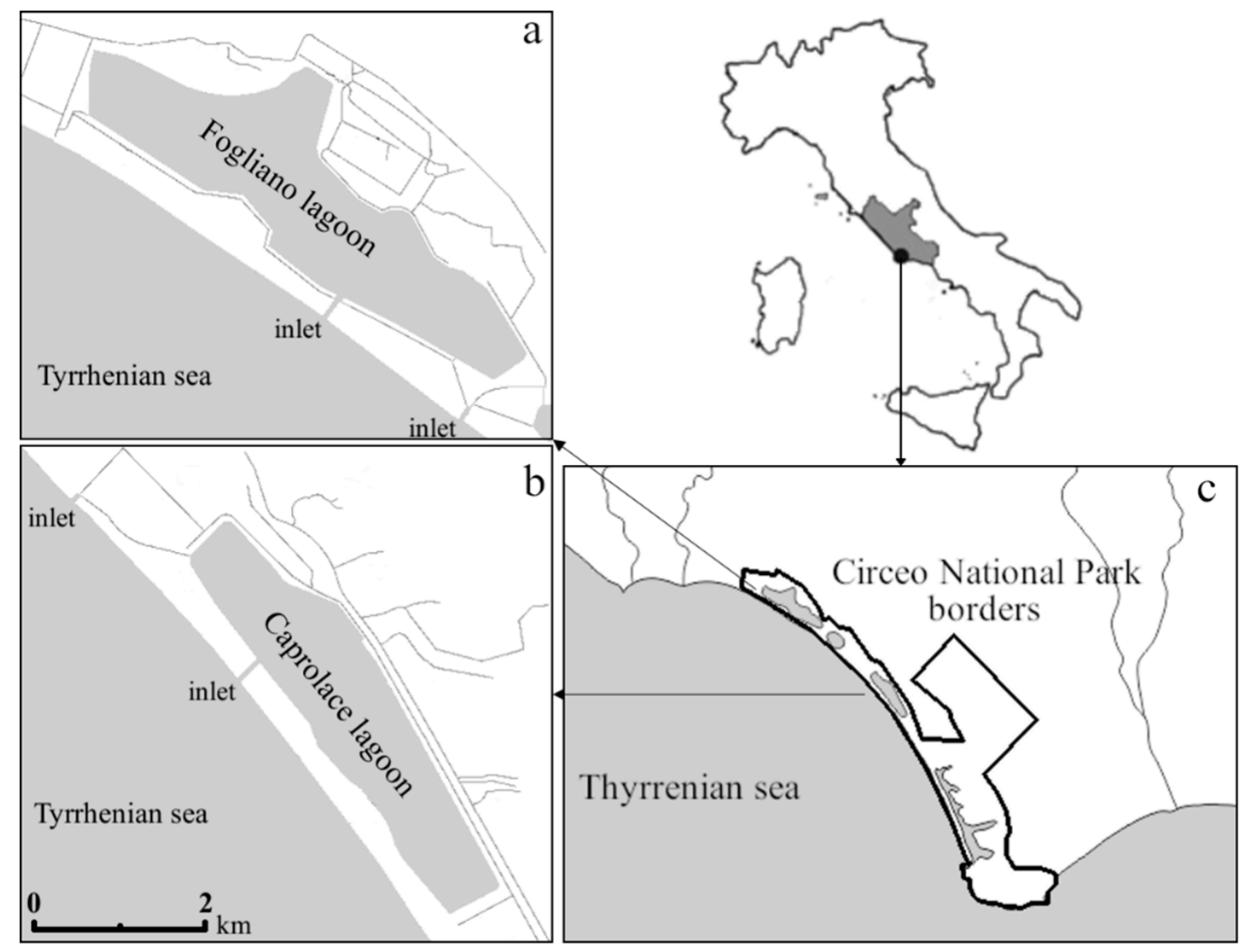

Figure 1. Study sites: the two coastal lagoons of Fogliano (a) and Caprolace (b) in the Circeo National Park, Central Italy (c). 
Table 1. Geo-morphological and hydrographic features of the two coastal lagoons of the Circeo National Park, Fogliano and Caprolace. Both lagoons fall in the category of non-tidal $(<50 \mathrm{~cm})$, euhaline lagoons (average $30 \mathrm{psu}$ ) of the Mediterranean ecoregion according to the classification of the transitional water under Directive 2000/60 EC (WFD).

\begin{tabular}{ccc}
\hline & Fogliano Lagoon & Caprolace Lagoon \\
\hline Latitude & $41^{\circ} 24^{\prime}$ & $41^{\circ} 21^{\prime}$ \\
Longitude & $12^{\circ} 54^{\prime}$ & $12^{\circ} 58^{\prime}$ \\
Perimeter $(\mathrm{km})$ & 11.2 & 8.4 \\
Surface $(\mathrm{ha})$ & 404 & 226 \\
Max Depth $(\mathrm{m})$ & 2.0 & 2.9 \\
Mean Depth $(\mathrm{m})$ & 0.9 & 1.3 \\
Volume $\left(\mathrm{m}^{3}\right)$ & $3,616,000$ & $2,923,783$ \\
$\mathrm{n}^{\circ}$ of tidal inlets & 2 & 2 \\
n $^{\circ}$ of tributaries & 0 & 0 \\
Tidal range $(\mathrm{m})$ & 0.23 & 0.21 \\
Rate of water exchange (days) & 60 & 90 \\
Annual average water & 20.3 & 19.4 \\
temperature $\left({ }^{\circ} \mathrm{C}\right)$ & 40.6 & 39.1 \\
Annual average Salinity (psu) & &
\end{tabular}

\subsection{Environmental Quality Assessment}

A methodology based on an expert judgement approach [38], developed for the ecological evaluation of transitional waters (WFD, 2000/60) with special reference to lagoon ecosystems in the Mediterranean area has been set to assess the environmental quality of Fogliano and Caprolace lagoons [39]. This method relies on the preliminary selection of several environmental descriptors of both direct and indirect human pressures acting on lagoon ecosystems. Hydro-morphology and the quality of water, as well as the use of the lagoon resources and the surrounding landscape, are taken into account and quantified for the calculation of indices. A detailed description of the selection of pressure indicators, their attribution to specific categories and quantification, data sources and methods of calculation of indices are given in Capoccioni et al. [39].

\subsection{Lipid Level and Contaminant Determination}

A total of 32 thick-lipped grey mullets, 16 from each lagoon, were collected during winter 2016 by trammel nets. At capture, fish were anaesthetized on ice and painlessly sacrificed (National Park authorization $\mathrm{n}^{\circ} \mathrm{PNC} / \mathrm{DIR} / 2016 / 4773$ ).

In the lab, individuals were weighed (to the nearest $\mathrm{g}$ ) and measured for total length (to the nearest $\mathrm{mm}$ ) and dissected for macroscopic gender assessment. Scales were taken and examined for ageing according to [40]. Skinned muscle tissue samples of approximately $15 \mathrm{~g}$ were collected from the dorsal part of the body, weighed, and freeze-dried (water loss during this process was registered).

\subsection{Fish Collection and Tissue Sampling}

A wide range of POPs was measured in muscle samples of individual fish. Contamination by polychlorinated biphenyls (PCBs) was assessed considering 29 congeners, including seven PCB indicators: 28, 52, 101, 118, 138, 153, and 180. Organochlorine pesticides (OCPs), such as chlordanes, dichlorodiphenyltrichloroethane and its metabolites (DDTs), hexachlorobenzene (HCB) and hexachlorocyclohexane isomers $(\mathrm{HCHs})$, were measured as well as polybrominated diphenyl ethers (PBDEs) and methoxylated brominated diphenyl ethers (MeO-BDEs). The following metals were also measured: zinc $(\mathrm{Zn})$, copper $(\mathrm{Cu})$, lead $(\mathrm{Pb})$, chromium $(\mathrm{Cr})$, cadmium $(\mathrm{Cd})$, and mercury (Hg). Muscle sample processing, lipid content measurements, POP and metals analysis are described in detail in Section S1 of the Supplementary Material. 
Concentrations of POPs were reported as $\mathrm{ng} \mathrm{g}^{-1}$ on both a lipid weight (lw) and a wet weight (ww) basis. Metals were reported in $\mu \mathrm{g} \mathrm{g}^{-1} \mathrm{ww}$.

\subsection{Quality Assurance/Quality Control}

The extraction, clean up, and fractionation steps were evaluated by measurement of the absolute recoveries of the internal standards (70-115\%). The peaks were quantified as targeted compounds if (1) the retention time matched that of the standard compound within $\pm 0.1 \mathrm{~min}$ and (2) the signal-to-noise ratio $(\mathrm{S} / \mathrm{N})$ was higher than 3:1. The limits of quantification (LOQs) were calculated as three times the standard deviation of the blank measurements mean. Procedural blanks were analyzed simultaneously within each batch of seven samples to check for interferences or contamination from solvent and glassware. Procedural blanks were consistent $(\mathrm{RSD}<30 \%)$ and therefore the mean value was calculated for each compound and subtracted from the sample values. The analytical procedures for POPs were validated through the analysis of certified material SRM 1945 (organics in whale blubber) for which deviations from certified values of less than $20 \%$ were recorded.

Samples with concentrations below LOQ were calculated as $\mathrm{df} \times \mathrm{LOQ}$, with " $\mathrm{df}$ " being the fraction of samples above LOQ. POP limits of quantification (LOQs) ranged between 0.1 and $0.3 \mathrm{ng} \mathrm{g}^{-1} \mathrm{ww}$.

As far as toxic metals were concerned, Certified Reference Materials (CRM) were purchased from the National Research Council, Canada (DORM-4, Fish protein for trace metals). Metals LOQs ranged between 0.001 and $0.078 \mu \mathrm{g} \mathrm{g}^{-1} \mathrm{ww}$.

\subsection{Data Analysis}

Mean length and weight $( \pm \mathrm{SE})$ were calculated for mullets grouped by gender and site, as well as mean $( \pm \mathrm{SE})$ age and annual growth rate $\left(\mathrm{GR}, \mathrm{cm}\right.$ year $\left.^{-1}\right)$, estimated according to [41] to allow for growth comparison between sites. Body condition was assessed individually using Le Cren condition factor (CF), calculated by the formula $(100 \times \mathrm{W}) / \mathrm{W}^{\prime}$, where $\mathrm{W}$ is the mass of an individual fish and $\mathrm{W}^{\prime}$ the predicted mass of a fish of the same total length [42], mean values $( \pm \mathrm{SE})$ were calculated for each sampling site. Statistical analyses were performed for each category of contaminants (i.e., $\sum_{6} \mathrm{PCBs}$, $\sum_{7} \mathrm{PCBs}, \sum \mathrm{PCBs}$, $\sum$ Chlordane, $\sum$ DDTs, HCB, $\sum$ HCHs, $\sum$ PBDEs, and $\left.\sum \mathrm{MeO}-\mathrm{BDEs}\right)$ and metals $(\mathrm{Zn}, \mathrm{Cu}, \mathrm{Pb}, \mathrm{Cr}, \mathrm{Cd}$, and $\mathrm{Hg}$ ), looking for differences between sites and gender. POPs data treatment has been done using lipid weight values since bioaccumulation of hydrophobic chemicals is influenced by lipid content of muscle tissue [43]. Conversely, to compare contamination levels found in this study with those observed in other Mediterranean locations and the Atlantic coast of Europe, data on a wet weight basis were also considered.

A two-way ANOVA was used to test for significant differences in contaminants concentration among sites and gender. Differences between groups of contaminants in all analyses were tested for significance using non-parametric methods (Kruskal-Wallis test) adjusted by Bonferroni correction.

\section{Results and Discussion}

\subsection{Environmental Quality Assessment}

The environmental status assessment performed for Fogliano and Caprolace accounts for a generally good quality status in both lagoons, and an overall limited anthropogenic impact (Figure 2). Fogliano and Caprolace have shown nevertheless to be sensitive to specific indicators of anthropogenic pressure (Figure 2). In particular, the state of maintenance of the tidal channels, and hence water renewal, and the inputs due to the use of surrounding land affect the lagoons, bringing about increased levels of Dissolved Inorganic Nitrogen (DIN) and chlorophyll-a concentration, and lower dissolved oxygen. Such outcomes on water quality are more pronounced in Fogliano, that experiences at a higher degree the consequences of reduced water exchange with the sea. This entails a reduced turnover (Table 1) and therefore a slower dilution run-off water nutrient input. In Caprolace, the highest impact is detected for pressures related to the use of land and resources, because of the larger share of the 
surrounding land affected by anthropogenic use, mostly for agriculture and livestock. In both lagoons, the presence of some non-priority pollutants (e.g., pesticides, PAHs, PCBs, and metals such as arsenic) and the presence of priority pollutants, such as nickel, lead, cadmium, and mercury, has been detected in the water column, albeit never over threshold values [44-46] and therefore never substantially affecting water quality.
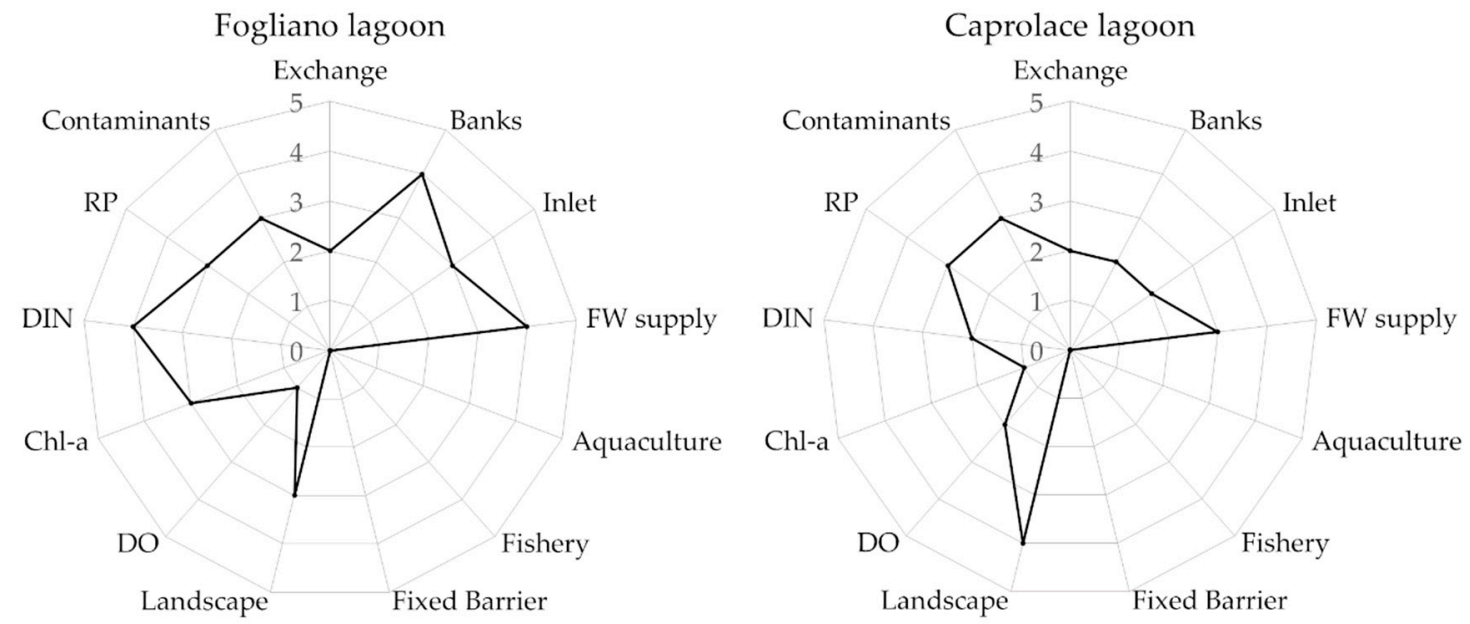

Figure 2. Environmental assessment of the lagoons: score values of indicators of anthropogenic pressure acting on Fogliano and Caprolace. Vectors represent: Water Exchange, Banks, Efficiency of Tidal Inlets and Freshwater supply (CPI-Morpho); Aquaculture, Fishery, Fixed barrier and Landscape (CPI-Use); Dissolved Oxygen (DO), Chlorophyll- $\alpha(\mathrm{Chl}-\alpha)$; Dissolved Inorganic Nitrogen (DIN), and Reactive Phosphorus (RP) CPI-Qual.

\subsection{Biological Features}

Mullet's biological characteristics are shown in Table 2. Data have been grouped by site and irrespective of gender (sex $50.0 \%$ and $60.3 \%$ of females respectively in the two lagoons) since biological parameters did not significantly differ for any attribute between males and females (Two-way ANOVA, $\mathrm{p}>0.05$, Table S1). Total length, weight, and condition factors showed no significant differences between sites. At Fogliano, mullets exhibit a significantly faster mean annual growth, amounting to

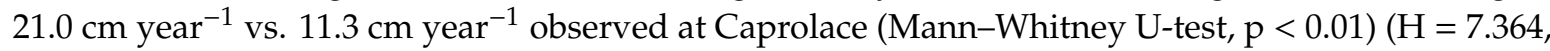
$\mathrm{p}<0.01)$, as well as a higher lipid content $(2.2 \%$ vs. $1.3 \%$ in Caprolace, $\mathrm{H}=5.549, \mathrm{p}<0.05)$. Such differences, along with a mean age significantly lower than those from Caprolace (Mann-Whitney U-test, $\mathrm{p}<0.05$ ), could be due to the higher trophic status documented by the habitat quality assessment in Fogliano lagoon (see DIN and Chl-a scores, Figure 2).

Table 2. Mean \pm SE of total length, weight, lipid content, age, annual growth rate, and of Le Cren's relative condition factor of thick-lipped mullet samples from Fogliano and Caprolace.

\begin{tabular}{|c|c|c|c|c|}
\hline & \multicolumn{2}{|c|}{ Fogliano Lagoon $(n=16)$} & \multicolumn{2}{|c|}{ Caprolace Lagoon $(n=16)$} \\
\hline & Mean & $\pm \mathrm{SE}$ & Mean & $\pm \mathrm{SE}$ \\
\hline Females (\%) & 50.0 & & 60.3 & \\
\hline Length $(\mathrm{cm})$ & 34.7 & 1.3 & 33.6 & 1.0 \\
\hline Weight $(\mathrm{g})$ & 744.8 & 63.9 & 573.1 & 36.6 \\
\hline$\%$ Lipids (on ww basis) & $2.2^{* *}$ & 0.2 & 1.4 & 0.2 \\
\hline Age (year) & 2.0 & 0.0 & $3.0 *$ & 0.0 \\
\hline Growth rate $\left(\mathrm{cm}^{-1} \mathrm{year}^{-1}\right)$ & $21.0 * *$ & 2.5 & 11.3 & 0.7 \\
\hline Le Cren's CF & 1.0 & 0.1 & 1.0 & 0.0 \\
\hline
\end{tabular}

Significant differences between the two lagoons are marked by a single $(\mathrm{p}<0.05)$ or double asterisk $(\mathrm{p}<0.01)$. 


\subsection{Organic Contaminants}

In most cases, compounds concentrations in fish muscle showed very low values in both sites, standing for a general low contamination pattern that agrees with the environmental quality assessment (Table 3). Two-way ANOVA (see Table S2) did not show a significant interaction effect of site and gender on contaminants $(\mathrm{p}>0.05)$, therefore further comparisons were carried out irrespective of sex, and evidenced some statistical differences for specific contaminants in mullets from the two lagoons (Table 3). These can be interpreted based on each specific environmental context and compared with results available in the scientific literature, dealing with grey mullet species contamination in Mediterranean and Atlantic transitional and marine habitats.

PCBs were found in all fishes from both lagoons. Median and range values of total PCBs amounted to $219 \mathrm{ng} \mathrm{g}^{-1} \mathrm{lw}$ (61.7-6134) and $212 \mathrm{ng} \mathrm{g}^{-1} \mathrm{lw}$ (81.7-945) in Fogliano and Caprolace, respectively, with no significant difference between sites (Table 3). The congeners that mostly contributed to the total PCB loads were PCB 153 (18.5\% vs. 22.2\% respectively for Fogliano and Caprolace) and PCB 138 $(12.3 \%$ vs. $10.9 \%)$. These percentages are in line with those observed in other fish species, such as the eel from Belgium [47,48] and from transitional environments in Italy [39,49,50]. In 1994, in the two coastal lagoons under study, Casini et al. [51] found, in muscle tissues of four species of grey mullets (C. aurata, C. saliens, C. ramada, and M. cephalus), similar total PCB concentrations. Overlapping results after nearly twenty years, despite the ban of PCBs since the 70s, can be explained by the persistence of this compound in Fogliano and Caprolace lagoons water and sediments. Results of the lagoon quality status carried out in this study highlighted the peculiar hydrological condition of this lagoon, with a reduced water exchange with the sea as well as occasional silting of the tidal channels. Dredging operations periodically carried out in the two lagoons to overcome this problem might easily remobilize contaminants no longer in use but accumulated in the sediments [52,53]. This seems to be testified by the fact that persistent contaminants such as PCBs, banned from several years, are still present in fish tissue in both lagoons.

Among the other organochlorine compounds (Tables 3 and S2), total Chlordane median concentrations in mullet muscle were 6.0 (3.0-191.0) $\mathrm{ng} \mathrm{g}^{-1} \mathrm{lw}$ and 8.2 (3.9-60.0) $\mathrm{ng} \mathrm{g}^{-1} \mathrm{lw}$, respectively in Fogliano and Caprolace, with no significant difference between sites (Mann-Whitney U-test, $p>0.05$ ). Median concentrations values of HCB were 3.2 (2.0-8.1) and 4.7 (2.9-8.4) $\mathrm{ng} \mathrm{g}^{-1} \mathrm{lw}$ in mullets from Fogliano and Caprolace respectively, the latter showing a significantly higher concentration for Fogliano (Mann-Whitney U-test, $\mathrm{p}<0.05$ ). The level of $\Sigma \mathrm{HCH}$ was on the other hand significantly higher in fish from Caprolace (Mann-Whitney U-test, $\mathrm{p}<0.01$ ), with a median value of $8.8(3.3-13) \mathrm{ng} \mathrm{g}^{-1}$ lw concerning $4.6(2.3-13) \mathrm{ng} \mathrm{g}^{-1} \mathrm{lw}$ in mullets from Fogliano. As for $\mathrm{HCH}$ isomers, mean levels of $\beta-\mathrm{HCH}$ and $\gamma-\mathrm{HCH}$ (which are, respectively, the most persistent and the most toxicological active $\mathrm{HCH}$ isomers [54]) contributed to $\Sigma \mathrm{HCH}$ levels $13-13 \%$ and $71-73 \%$, respectively in Fogliano and Caprolace, $\gamma-\mathrm{HCH}$ being, therefore, the dominant isomer. Such a difference in $\mathrm{HCH}$ compounds, prone to accumulate in the sediments through adsorption processes and direct sedimentation of suspended particulate matter [55], could be due to their accumulation to a greater extent by mullets in Caprolace, older than those in Fogliano, as a function of the exposure time. Additionally, the pressures related to the use of land and resources, mostly for agriculture and livestock, more pronounced in the area surrounding the southernmost of the two lagoons, could support this hypothesis.

$\Sigma \mathrm{HCH}$ levels found in Caprolace mullets were generally comparable with those reported in mullets from other Mediterranean lagoons [54] (Table 4). In contrast, results from Fogliano were lower than those reported by Naso et al. [56] and Ameur et al. [54] (mean values, 24.1 and $6.7 \mathrm{ng} \mathrm{g}^{-1} \mathrm{lw}$, respectively) for mullets from Mediterranean coastal waters (Table 4).

Total PBDE median concentrations were not significantly different in fish from the two lagoons, amounting to $1.9 \mathrm{ng} \mathrm{g}^{-1} \mathrm{lw}$ (range, 1.0-410.8) in the specimens from Fogliano and $3.2 \mathrm{ng} \mathrm{g}^{-1}$ Iw (range, 1.2-83.7) in those from Caprolace. Although both exceeded the EQSBIOTA threshold (Biota Environmental Quality Standard: $0.0085 \mathrm{ng} \mathrm{g}^{-1} \mathrm{ww}$ ) set by Directive 2013/39/UE and by National Decree 172/2015 (Table S4), the detected values do not suggest significant contamination by 
PBDEs. It has been stated that the EU EQS limit should be revised [57] as they are too low given that more than $70 \%$ of the analyzed fish at the European aquatic systems level had results exceeding the EQSBIOTA [58]. As far as PBDE congeners are concerned, most of them showed low concentrations: BDE 47, BDE 100 and BDE 154 made up about 96\% and 86\% on average of the total PBDE load respectively for Fogliano and Caprolace. The dominant compound was BDE-47 (47\%), which is usually the most abundant compound in fish, as a result of its highest bioaccumulation factor [59]. As expected, several authors made the same observations in previous studies in fish and other organisms [60-63]. As for the ratio between PBDE-99 and PBDE-100, considered an indicator of the organism metabolic capacity [60], fish from the two lagoons displayed a comparable ratio of 1:9 and 1:4 (Fogliano and Caprolace respectively), in line with the mean BDE-99: BDE-100 ratio in fish from marine coastal areas that are not excessively polluted [63].

Concerning MeO-PBDEs, a significantly higher mean concentration was found in Fogliano, but in any case levels observed in mullet muscle tissue from both lagoons are noticeably higher than those found in the same lagoons in the European eel [39]. Such a difference can be accounted for by the different trophic behavior of the grey thick-lipped mullet compared to the eel. The filter-feeding habits of this mugilid encompasses ingestion of detritus, algae and cyanobacteria, which are the natural sources of these compounds [64,65]. Therefore, the high MeO-PBDEs levels, that have no anthropogenic origin, in mullets from Fogliano could be linked to a more intense primary production that follows the nutrient input loads. Such higher loads in this lagoon, coupled with a reduced water renewal, is an issue that has been highlighted by the environmental assessment (Figure 2). High concentrations of MeO-PBDEs in urchins from the Bizerte lagoon have been found with site-specific differences, in turn related to different levels of agricultural inputs [66], while seasonal variations in their levels in blue mussels in the Baltic Sea have been explained by summer peaks of algal production [67].

As for DDTs, a significant difference was detected between Fogliano and Caprolace thick-lipped grey mullets $(\mathrm{p}<0.01)$, with the former showing higher median values $\left(58.0 \mathrm{ng} \mathrm{g}^{-1} \mathrm{lw}\right.$, range: 25.7-949.9) than those from Caprolace (49.9 $\mathrm{ng} \mathrm{g}^{-1} \mathrm{lw}$, range: 31.1-292.0). Median concentrations expressed on a wet weight basis (1.3 and $0.5 \mathrm{ng} \mathrm{g}^{-1}$, respectively) are much lower than the EQSBIOTA limit (100 $\mathrm{ng} \mathrm{g}^{-1} \mathrm{ww}$, Table 3) established under National Decree 172/2015 [46] for fish with $<5 \%$ lipid. $\Sigma$ DDT values in mullets from the two study sites, and the higher values in fish from Fogliano, are of the same order of magnitude as those reported for grey mullets from other Mediterranean transitional waters (Table 4), such as the Bizerte lagoon in Tunisia [54] and the Ebro delta in Portugal [68], while they are sensibly lower than those reported for marine habitats such as the Marmara Sea in Turkey [69] and from the coastal waters of Italy [56]. It is not surprising that the banned DDT and its degradation products DDE and DDT are found in fish and other organisms because their presence in sediments persists even for decades. They can return to the water column or surface sediments and in the food chain in case of disturbance or handling of sediments such as those due to dredging [52,53]. Such intervention, as already pointed out before, occurs in Fogliano, and probably accounts for the higher DDT levels found in mullet from this lagoon.

More specifically for DDT and its metabolites, Hitch and Day [70] and Zhou et al. [71] highlighted that the ratio (DDE/DDD)/DDTs can be used to assess the chronology of DDT inputs to aquatic ecosystems. In general, a ratio higher than 0.5 indicates long-term biotransformation of DDT to DDE and DDD, while a ratio of less than 0.5 may indicate the recent input of DDT [70,71]. In this study, observed ratios (Fogliano $=0.79$; Caprolace $=0.82$ ) stand for past DDT pollution, likely used in agriculture in the area surrounding the two lagoons. The Agro Pontino plain, where both are located, has become a reclaimed area since the 20s, where a progressively intensified agriculture and livestock has been occurring. Furthermore, the history of this territory should be taken into account, where an extensive program for malaria eradication was performed since the end of the Second World War, in the period 1944-1965, making use of DDT spread with airplanes [72,73]. Therefore, the presence of DDTs in fish in this area $[39,74]$ testifies to the still on-going contamination, as a consequence of past massive use and diffused pollution from intensive agriculture [53]. 
Table 3. Detection frequencies, medians, mean concentrations $( \pm \mathrm{SD})$ and ranges of organic compounds (ng $\left.\mathrm{g}^{-1} \mathrm{lw}\right)$ analyzed in $C$. labrosus muscle from Fogliano and Caprolace.

\begin{tabular}{|c|c|c|c|c|c|c|c|c|c|c|c|c|}
\hline \multirow{2}{*}{ Substance } & \multicolumn{6}{|c|}{ Fogliano Lagoon $(n=16)$} & \multicolumn{6}{|c|}{ Caprolace Lagoon $(n=16)$} \\
\hline & Det. Freq. & Median & Mean & SD & Min & Max & Det. Freq. & Median & Mean & SD & Min & Max \\
\hline PCB 28 & $0 \%$ & 0.00 & 0.00 & 0.00 & 0.00 & 0.00 & $0 \%$ & 0.00 & 0.00 & 0.00 & 0.00 & 0.00 \\
\hline PCB 52 & $56 \%$ & 4.73 & 11.74 & 7.45 & 0.75 & 122.40 & $38 \%$ & 0.75 & 5.14 & 1.84 & 0.75 & 23.13 \\
\hline PCB 49 & $19 \%$ & 0.40 & 3.91 & 2.57 & 0.40 & 40.79 & $31 \%$ & 0.40 & 3.55 & 1.42 & 0.40 & 19.04 \\
\hline PCB 74 & $0 \%$ & 0.05 & 0.05 & 0.00 & 0.05 & 0.05 & $6 \%$ & 0.05 & 0.69 & 0.64 & 0.05 & 10.31 \\
\hline PCB 95 & $56 \%$ & 3.77 & 8.92 & 5.52 & 0.45 & 90.40 & $56 \%$ & 4.33 & 6.64 & 2.06 & 0.45 & 23.51 \\
\hline PCB 101 & $100 \%$ & 15.39 & 38.69 & 22.68 & 4.48 & 376.72 & $100 \%$ & 17.05 & 24.37 & 4.45 & 10.64 & 59.46 \\
\hline PCB 99 & $100 \%$ & 18.29 & 28.98 & 10.08 & 7.50 & 175.81 & $100 \%$ & 14.25 & 20.06 & 3.01 & 10.54 & 48.66 \\
\hline РСВ 110 & $38 \%$ & 0.28 & 15.24 & 12.43 & 0.28 & 201.08 & $31 \%$ & 0.28 & 5.99 & 2.93 & 0.28 & 35.22 \\
\hline PCB 105 & $100 \%$ & 3.85 & 13.73 & 9.25 & 1.00 & 151.70 & $100 \%$ & 5.41 & 7.75 & 1.59 & 2.51 & 22.63 \\
\hline РСВ 118 & $100 \%$ & 16.17 & 41.78 & 24.00 & 4.95 & 399.01 & $100 \%$ & 16.06 & 23.52 & 4.62 & 8.07 & 63.10 \\
\hline РСВ 151 & $6 \%$ & 0.03 & 10.35 & 10.33 & 0.03 & 165.29 & $0 \%$ & 0.03 & 0.03 & 0.00 & 0.03 & 0.03 \\
\hline РСВ 149 & $75 \%$ & 13.69 & 18.86 & 6.76 & 0.80 & 113.48 & $56 \%$ & 10.24 & 17.79 & 5.96 & 0.80 & 68.90 \\
\hline PCB 146 & $100 \%$ & 10.90 & 21.13 & 9.59 & 3.82 & 162.94 & $100 \%$ & 6.88 & 10.84 & 2.29 & 2.86 & 34.03 \\
\hline PCB 153 & $100 \%$ & 42.16 & 104.25 & 54.92 & 17.11 & 920.43 & $100 \%$ & 41.74 & 58.30 & 10.97 & 21.13 & 171.78 \\
\hline РCB 138 & $81 \%$ & 22.91 & 68.37 & 41.63 & 0.63 & 687.24 & $75 \%$ & 25.71 & 38.70 & 9.88 & 0.63 & 124.38 \\
\hline РСВ 187 & $100 \%$ & 14.88 & 37.68 & 19.82 & 5.69 & 331.65 & $100 \%$ & 11.66 & 19.60 & 4.78 & 4.89 & 70.07 \\
\hline РCB 183 & $100 \%$ & 3.59 & 15.29 & 10.49 & 1.17 & 172.15 & $100 \%$ & 3.59 & 6.37 & 1.65 & 1.48 & 22.90 \\
\hline РСВ 128 & $100 \%$ & 3.48 & 11.27 & 6.89 & 1.12 & 113.86 & $100 \%$ & 4.16 & 6.58 & 1.50 & 1.92 & 19.57 \\
\hline РСВ 174 & $88 \%$ & 2.07 & 5.80 & 3.01 & 0.75 & 50.14 & $100 \%$ & 2.63 & 4.76 & 1.34 & 0.95 & 17.11 \\
\hline РCB 177 & $88 \%$ & 1.88 & 7.98 & 5.36 & 0.68 & 87.97 & $81 \%$ & 2.67 & 4.91 & 1.47 & 0.68 & 18.39 \\
\hline РCB 171 & $75 \%$ & 1.49 & 6.72 & 4.81 & 0.58 & 78.76 & $69 \%$ & 1.53 & 2.74 & 0.73 & 0.58 & 9.78 \\
\hline PCB 156 & $69 \%$ & 1.54 & 6.85 & 4.96 & 0.60 & 80.91 & $81 \%$ & 2.01 & 2.99 & 0.71 & 0.60 & 9.59 \\
\hline PCB 180 & $100 \%$ & 12.78 & 62.51 & 44.99 & 4.14 & 735.65 & $100 \%$ & 13.07 & 22.46 & 5.86 & 4.54 & 81.22 \\
\hline PCB 170 & $100 \%$ & 5.20 & 26.73 & 19.64 & 1.62 & 320.59 & $100 \%$ & 5.44 & 9.49 & 2.47 & 2.08 & 32.74 \\
\hline РCB 199 & $88 \%$ & 2.12 & 13.50 & 10.12 & 0.68 & 164.83 & $81 \%$ & 2.63 & 4.73 & 1.31 & 0.68 & 17.18 \\
\hline PCB 196/203 & $88 \%$ & 2.18 & 15.62 & 12.28 & 0.70 & 199.46 & $88 \%$ & 2.61 & 4.85 & 1.33 & 0.70 & 18.34 \\
\hline PCB 194 & $100 \%$ & 3.04 & 13.01 & 8.68 & 0.99 & 142.59 & $100 \%$ & 3.31 & 5.25 & 1.32 & 0.99 & 18.84 \\
\hline РCB 206 & $38 \%$ & 0.33 & 2.90 & 2.13 & 0.33 & 34.81 & $44 \%$ & 0.33 & 1.12 & 0.29 & 0.33 & 3.85 \\
\hline РCB 209 & $25 \%$ & 0.28 & 1.34 & 0.82 & 0.28 & 13.32 & $44 \%$ & 0.28 & 1.18 & 0.29 & 0.28 & 3.30 \\
\hline$\sum_{6} \mathrm{PCBs}$ & & 100.10 & 285.55 & 171.52 & 27.09 & 2842.44 & & 104.54 & 148.98 & 31.44 & 38.06 & 436.05 \\
\hline $\bar{\sum}_{7} \mathrm{PCBs}$ & & 117.45 & 327.33 & 195.50 & 32.04 & 3241.45 & & 122.94 & 172.50 & 35.92 & 46.13 & 491.51 \\
\hline$\sum \mathrm{PCBs}$ & & 219.15 & 613.19 & 370.27 & 61.68 & 6134.03 & & 212.36 & 320.38 & 71.97 & 80.68 & 944.48 \\
\hline
\end{tabular}


Table 3. Cont.

\begin{tabular}{|c|c|c|c|c|c|c|c|c|c|c|c|c|}
\hline \multirow{2}{*}{ Substance } & \multicolumn{6}{|c|}{ Fogliano Lagoon $(n=16)$} & \multicolumn{6}{|c|}{ Caprolace Lagoon $(\mathrm{n}=16)$} \\
\hline & Det. Freq. & Median & Mean & SD & Min & Max & Det. Freq. & Median & Mean & SD & Min & Max \\
\hline oxy-chlordane $(\mathrm{OxC})$ & $31 \%$ & 0.43 & 1.15 & 0.46 & 0.43 & 7.82 & $75 \%$ & $1.50^{*}$ & 1.55 & 0.23 & 0.43 & 3.69 \\
\hline trans-chlordane (TC) & $75 \%$ & 1.18 & 1.99 & 0.73 & 0.65 & 12.70 & $88 \%$ & 1.73 & 2.15 & 0.39 & 0.65 & 6.99 \\
\hline cis-chlordane (CC), & $63 \%$ & 1.30 & 4.47 & 3.23 & 0.63 & 52.90 & $94 \%$ & 1.34 & 2.36 & 0.71 & 0.63 & 12.61 \\
\hline trans-nonachlor (TN) & $94 \%$ & 1.81 & 8.37 & 5.68 & 0.78 & 92.96 & $100 \%$ & 2.23 & 4.33 & 1.59 & 1.55 & 27.51 \\
\hline cis-nonachlor $(\mathrm{CN})$ & $75 \%$ & 1.17 & 2.77 & 1.46 & 0.50 & 24.47 & $50 \%$ & 0.73 & 1.64 & 0.56 & 0.50 & 9.22 \\
\hline$\sum$ Clordane & & 5.92 & 18.75 & 11.53 & 2.98 & 190.86 & & 8.16 & 12.02 & 3.33 & 3.90 & 60.03 \\
\hline HCB & & 3.18 & 3.62 & 0.41 & 1.97 & 8.14 & & $4.72 *$ & 4.77 & 0.35 & 2.97 & 8.40 \\
\hline $\mathrm{a}-\mathrm{HCH}$ & $44 \%$ & 0.50 & 0.87 & 0.11 & 0.50 & 1.63 & $69 \%$ & 1.31 & 1.14 & 0.13 & 0.50 & 2.16 \\
\hline b-HCH & $19 \%$ & 0.50 & 0.68 & 0.10 & 0.50 & 1.62 & $44 \%$ & 0.50 & 1.06 & 0.23 & 0.50 & 3.94 \\
\hline $\mathrm{g}-\mathrm{HCH}$ & $100 \%$ & 3.10 & 3.77 & 0.60 & 1.25 & 10.54 & $100 \%$ & $6.88^{* *}$ & 6.08 & 0.63 & 2.26 & 9.72 \\
\hline$\sum \mathrm{HCH}$ & & 4.36 & 5.32 & 0.72 & 2.25 & 12.50 & & $8.81 *$ & 8.28 & 0.83 & 3.26 & 12.84 \\
\hline PBDE 28 & $6 \%$ & 0.06 & 0.48 & 0.42 & 0.06 & 6.81 & $25 \%$ & 0.06 & 0.49 & 0.20 & 0.06 & 2.06 \\
\hline PBDE 47 & $100 \%$ & 1.23 & 22.02 & 20.37 & 0.39 & 327.53 & $100 \%$ & 1.55 & 9.34 & 4.15 & 0.61 & 57.21 \\
\hline PBDE 100 & $44 \%$ & 0.21 & 4.54 & 3.99 & 0.21 & 64.28 & $63 \%$ & 0.59 & 2.31 & 0.89 & 0.21 & 10.14 \\
\hline PBDE 99 & $31 \%$ & 0.18 & 0.63 & 0.35 & 0.18 & 5.79 & $56 \%$ & 0.53 & 0.74 & 0.17 & 0.18 & 2.19 \\
\hline PBDE 154 & $31 \%$ & 0.15 & 0.74 & 0.39 & 0.15 & 6.36 & $44 \%$ & 0.15 & 1.52 & 0.66 & 0.15 & 9.78 \\
\hline PBDE 153 & $0 \%$ & 0.03 & 0.03 & 0.00 & 0.03 & 0.03 & $13 \%$ & 0.03 & 0.23 & 0.16 & 0.03 & 2.41 \\
\hline PBDE 183 & $100 \%$ & 0.00 & 0.00 & 0.00 & 0.00 & 0.00 & $100 \%$ & 0.00 & 0.00 & 0.00 & 0.00 & 0.00 \\
\hline$\sum$ PBDE & & 1.85 & 28.45 & 25.50 & 1.01 & 410.79 & & 3.23 & 14.63 & 6.09 & 1.23 & 83.67 \\
\hline 2-MeO-BDE68 & $100 \%$ & 6.37 & 7.84 & 1.54 & 1.52 & 22.54 & $100 \%$ & 3.55 & 4.16 & 0.60 & 1.10 & 8.17 \\
\hline 6-MeO-BDE47 & $100 \%$ & $108.82^{* *}$ & 105.25 & 14.76 & 8.50 & 181.03 & $100 \%$ & 25.03 & 33.58 & 6.13 & 10.80 & 108.74 \\
\hline$\sum \mathrm{MeO}-\mathrm{BDE}$ & & $116.55 * *$ & 113.10 & 15.72 & 10.02 & 203.57 & $0 \%$ & 29.79 & 37.74 & 6.20 & 12.66 & 110.78 \\
\hline op-DDD & $100 \%$ & 0.00 & 0.00 & 0.00 & 0.00 & 0.00 & $100 \%$ & 0.00 & 0.00 & 0.00 & 0.00 & 0.00 \\
\hline op-DDT & $100 \%$ & 0.00 & 0.00 & 0.00 & 0.00 & 0.00 & $100 \%$ & 0.00 & 0.00 & 0.00 & 0.00 & 0.00 \\
\hline pp-DDE & $100 \%$ & 46.78 & 94.16 & 39.90 & 20.18 & 680.60 & $100 \%$ & 41.40 & 65.58 & 15.82 & 22.13 & 245.06 \\
\hline pp-DDD & $13 \%$ & 0.10 & 4.99 & 3.76 & 0.10 & 58.16 & $0 \%$ & 0.10 & 0.10 & 0.00 & 0.10 & 0.10 \\
\hline pp-DDT & $100 \%$ & 11.71 & 26.37 & 12.61 & 4.00 & 211.08 & $100 \%$ & 11.64 & 14.19 & 2.90 & 0.06 & 46.79 \\
\hline$\sum \mathrm{DDT}$ & & $58.00 * *$ & 125.51 & 56.07 & 25.69 & 949.85 & & 49.86 & 79.87 & 18.33 & 31.14 & 291.95 \\
\hline
\end{tabular}

$\sum_{6} \mathrm{PCBs}$ is the sum of the six indicators $28,52,101,138,153$, and 180. $\sum_{7} \mathrm{PCBs}$ is the sum of the seven indicators $28,52,101,118,138,153$, and 180. Significant differences between the two lagoons are marked by a single $(\mathrm{p}<0.05)$ or double asterisk $(\mathrm{p}<0.01)$ (Mann-Whitney $\mathrm{U}$ tests, Bonferroni corrected. In bold are reported the groups of contaminants to distinguish them in the table from the single pollutants. 
Table 4. Concentration of organochlorine compound ranges or mean values ( \pm SD where available) (ng $\mathrm{g}^{-1}$ ) in grey mullet (Mugilidae) muscle tissue available in the scientific literature of other Mediterranean locations, in the Atlantic coast of Europe and from the present study.

\begin{tabular}{|c|c|c|c|c|c|c|c|c|c|c|c|c|c|c|}
\hline Country & Site & Year & Species & $1 w / d w / w w$ & $\sum$ PCBs & $\sum_{6} \mathrm{PCBs}$ & $\sum_{7}$ PCBs & $\sum$ DDT & НСВ & $\sum \mathrm{HCHs}$ & $\sum$ PBDE & $\sum$ MeO-PBDEs & $\sum$ Chlordane & Source \\
\hline Portugal & Douro Estuary & 2002 & MC & $\mathrm{dw}$ & $311.0 \pm 58.0$ & & & $65.0 \pm 35.0$ & & & & & & [78] \\
\hline Portugal & Mondego & 2008 & $\mathrm{CL}$ & ww & & 0.6 & & & & & & & & [79] \\
\hline Portugal & Mondego & 2008 & LA & ww & & 1.0 & & & & & & & & [79] \\
\hline Portugal & Mondego & 2008 & LR & ww & & 5.0 & & & & & & & & [79] \\
\hline Spain & Ebro Delta & 1992 & MC & lw & & & $271.0 \pm 111.0$ & $546.0 \pm 226.0$ & $1138.0 \pm 410.0$ & & & & & [68] \\
\hline France & $\begin{array}{l}\text { Gironde } \\
\text { Estuary }\end{array}$ & $\mathrm{nr}$ & LR & $\mathrm{dw}$ & & & $108.0 \pm 60.0$ & & & & & & & [80] \\
\hline France & Vilaine estuary & 2005 & LR & $d w$ & & & 125.9 & 19.5 & & 1.5 & 6.7 & & & [81] \\
\hline France & Vilaine River & 2005 & LR & $d w$ & & & 203.4 & 23.8 & & 4.8 & 10.1 & & & [81] \\
\hline France & $\begin{array}{l}\text { Vaccare's } \\
\text { Lagoon }\end{array}$ & 2002-2005 & $\begin{array}{c}\text { Mugilidae } \\
\text { spp. }\end{array}$ & $d w$ & & & & & $0.3-9.1$ & $171.8-112.4$ & & & & [82] \\
\hline Italy & Fogliano & 1994 & LA & ww & $12-23$ & & & $0.6-2.8$ & $0.0-0.1$ & $0.0-0.0$ & & & & [51] \\
\hline Italy & Fogliano & 1994 & LS & ww & $60-150$ & & & $2.0-4.0$ & $0.02-0.0$ & $0.0-0.1$ & & & & [51] \\
\hline Italy & Fogliano & 1994 & LR & ww & $11-50$ & & & $0.8-4.8$ & $0.1-0.1$ & $0.0-0.0$ & & & & [51] \\
\hline Italy & Fogliano & 1994 & MC & ww & $7-31$ & & & $0.4-1.4$ & $0.0-0.0$ & $0.0-0.0$ & & & & [51] \\
\hline Italy & Caprolace & 1995 & LA & ww & 3-150 & & & $1.5-31.5$ & $0.0-2.0$ & & & & & [51] \\
\hline Italy & Fogliano & 2016 & $\mathrm{CL}$ & lw & $613.1 \pm 1481.8$ & $285.6 \pm 171.5$ & $327.3 \pm 782.0$ & $125.5 \pm 224.3$ & $3.6 \pm 1.7$ & $5.3 \pm 2.9$ & $141.5 \pm 94.1$ & $113.1 \pm 15.7$ & $18.8 \pm 6.1$ & $\begin{array}{c}\text { Present } \\
\text { study }\end{array}$ \\
\hline Italy & Caprolace & 2016 & $\mathrm{CL}$ & lw & $320.4 \pm 287.9$ & $149.1 \pm 31.4$ & $172.5 \pm 143.7$ & $79.9 \pm 73.3$ & $4.8 \pm 1.4$ & $8.3 \pm 3.3$ & $52.4 \pm 39.4$ & $37.7 \pm 6.2$ & $12.0 \pm 13.3$ & $\begin{array}{c}\text { Present } \\
\text { study }\end{array}$ \\
\hline Italy & Med Sea & $\mathrm{nr}$ & $\mathrm{MC}$ & $1 \mathrm{w}$ & 1042.0 & & & 596.0 & & 24.1 & & & & {$[56]$} \\
\hline Italy & Tyrrhenian Sea & 2004 & MC & ww & & & 9.0 & & & & & & & [83] \\
\hline Italy & Adriatic Sea & 2005 & MC & lw & 1210 ** & & & & & & & & & [84] \\
\hline Tunisia & Radès & $\mathrm{nr}$ & LA & lw & $96.0 *$ & & 2350.0 & & & & & & & [85] \\
\hline Tunisia & Raoued & $\mathrm{nr}$ & LA & lw & 52.0 * & & 961.0 & & & & & & & [85] \\
\hline Tunisia & Bizerte & 2010 & MC & lw & $249.0 \pm 56.7$ & & $220.8 \pm 89.3$ & $95.4 \pm 30.5$ & & $6.7 \pm 6.1$ & $45.3 \pm 31.1$ & $\underset{* * *}{100.7 \pm 137.4}$ & & [54] \\
\hline Tunisia & MedSea & 2010 & MC & $1 \mathrm{w}$ & $109.0 \pm 13.7$ & & $97.6 \pm 12.6$ & $15.4 \pm 11.0$ & & $1.8 \pm 0.65$ & $7.8 \pm 2.4$ & $293.1_{* * *} \pm 179.9$ & & [54] \\
\hline Turkey & Marmara Sea & 2003 & $\mathrm{MC}$ & lw & & & 404.0 & 731.4 & & 224.7 & & & & [69] \\
\hline
\end{tabular}

Species: Mugil cephalus, MC; Liza ramada, LR; Liza aurata, LA; Liza saliens, LS; Chelon labrosus, CL. $\mathrm{nr}=$ not reported; * ww; ** sum of PCB52, PCB60, PCB77, PCB101, PCB105, PCB118, PCB138, PCB153, PCB156, PCB180; *** sum of 2-MeO-BDE-68, 5-MeO-BDE-47, 6-MeO-BDE-47. 


\subsection{Metals}

All the considered metals, except for $\mathrm{Hg}$, showed very low contamination levels (Table 5), also in comparison with results from other Mediterranean transitional and marine environments (Table 6). The same as metals, two-way analysis of variance (ANOVA, see Table S3) did not evidence significant interaction effects of site and gender on contaminants $(p>0.05)$, and therefore further comparisons were carried out irrespective of sex (Table 5).

Table 5. Detection frequencies, medians, mean concentrations $( \pm \mathrm{SD})$, and ranges of metals $\left(\mu \mathrm{g} \mathrm{g}^{-1} \mathrm{ww}\right)$ detected in C. labrosus muscle from Fogliano and Caprolace.

\begin{tabular}{|c|c|c|c|c|c|c|c|c|c|c|c|c|}
\hline \multirow[b]{2}{*}{ Substance } & \multicolumn{6}{|c|}{ Fogliano Lagoon $(\mathrm{n}=16)$} & \multicolumn{6}{|c|}{ Caprolace Lagoon $(n=16)$} \\
\hline & $\begin{array}{l}\text { Det. } \\
\text { Freq. }\end{array}$ & Median & Mean & $\pm \mathrm{SD}$ & Min & Max & $\begin{array}{l}\text { Det. } \\
\text { Freq. }\end{array}$ & Median & Mean & $\pm \mathrm{SD}$ & Min & Max \\
\hline $\mathrm{Cu}$ & $100 \%$ & 0.367 & 0.732 & 0.266 & 0.105 & 4.567 & $0 \%$ & 0.312 & 0.341 & 0.050 & 0.114 & 0.689 \\
\hline $\mathrm{Zn}$ & $100 \%$ & 5.189 & 5.463 & 0.466 & 1.658 & 9.822 & $0 \%$ & 5.871 & 6.106 & 0.635 & 2.985 & 11.858 \\
\hline $\mathrm{Cr}$ & $25 \%$ & 0.000 & 0.002 & 0.001 & 0.000 & 0.019 & $38 \%$ & 0.000 & 0.003 & 0.001 & 0.000 & 0.015 \\
\hline $\mathrm{Cd}$ & $50 \%$ & 0.000 & 0.000 & 0.000 & 0.000 & 0.000 & $69 \%$ & $0.000 *$ & 0.001 & 0.000 & 0.000 & 0.005 \\
\hline $\mathrm{Pb}$ & $38 \%$ & 0.000 & 0.002 & 0.001 & 0.000 & 0.011 & $31 \%$ & 0.000 & 0.003 & 0.002 & 0.000 & 0.024 \\
\hline $\mathrm{Hg}$ & $100 \%$ & 0.036 & 0.050 & 0.010 & 0.010 & 0.168 & $0 \%$ & 0.080 ** & 0.095 & 0.014 & 0.031 & 0.240 \\
\hline
\end{tabular}

Significant differences between lagoons are marked by a single $(\mathrm{p}<0.05)$ or double asterisk $(\mathrm{p}<0.01)$ (Mann-Whitney $\mathrm{U}$ tests Bonferroni corrected).

Specifically, for mercury, values found in mullet muscle tissues were high in both sites $\left(0.04 \mu \mathrm{g} \mathrm{g}^{-1} \mathrm{ww}\right.$ and $0.08 \mu \mathrm{g} \mathrm{g}^{-1} \mathrm{ww}$, for Fogliano and Caprolace respectively), with samples from Caprolace being significantly higher than in Fogliano $(p<0.01)$. Such concentrations are above the EQSBIOTA limits for fish (i.e., $0.02 \mu \mathrm{g} \mathrm{g}^{-1} \mathrm{ww}$ ). This may likely be attributed to an accumulation of this metal in the sediments $[75,76]$, but in the case of Fogliano and Caprolace, its origin cannot be explained based on known past or present activities or on impacts in the area. The higher Hg concentration in Caprolace compared to Fogliano mullets, on the other hand, is probably due to a longer permanence of fish in the lagoon, established by the larger body size associated with age, and thus to prolonged exposure [77]. 
Table 6. Metal mean concentration $\left( \pm\right.$ SD where available) $\left(\mu \mathrm{g} \mathrm{g}^{-1}\right)$ in grey mullets (Mugilidae) muscle tissue available in the scientific literature relative to sites from other Mediterranean locations, the Atlantic coast of Europe, and from the present study.

\begin{tabular}{|c|c|c|c|c|c|c|c|c|c|c|c|}
\hline Country & Site & Year & Species & $w w / d w$ & $\mathrm{Zn}$ & $\mathrm{Cu}$ & $\mathrm{Hg}$ & $\mathrm{Cr}$ & $\mathrm{Cd}$ & $\mathbf{P b}$ & Source \\
\hline Portugal & Rosàrio & $\mathrm{nr}$ & CL & $d w$ & $23.30 \pm 7.80$ & $1.60 \pm 0.10$ & & & $0.90 \pm 0.10$ & $3.70 \pm 0.60$ & [86] \\
\hline Portugal & Hortas & $\mathrm{nr}$ & CL & $\mathrm{dw}$ & $22.50 \pm 4.00$ & $0.94 \pm 0.20$ & & & $0.40 \pm 0.02$ & $1.50 \pm 0.40$ & [86] \\
\hline Portugal & S. Joao da Talha & $\mathrm{nr}$ & CL & $\mathrm{dw}$ & $24.70 \pm 4.30$ & $1.50 \pm 0.30$ & & & $0.30 \pm 0.01$ & $1.10 \pm 0.10$ & [86] \\
\hline Spain & Guadalquivir estuary & 1998 & LR & ww & $8.50 \pm 5.90$ & $0.50 \pm 0.30$ & & & $<0.02$ & & [87] \\
\hline Spain & Bacuta reservoir & 2002 & LA & ww & 6.07 & 0.50 & 0.01 & 0.04 & 0.03 & 0.03 & [88] \\
\hline Spain & Liebre reservoir & 2002 & LA & ww & 8.41 & 0.60 & 0.01 & 0.03 & 0.02 & 0.03 & [88] \\
\hline Spain & San Carlos reservoir & 2002 & LA & ww & 3.87 & 0.20 & 0.01 & 0.03 & 0.01 & 0.04 & [88] \\
\hline Spain & San Juan reservoir & 2002 & LA & ww & 3.10 & 0.40 & 0.01 & 0.04 & 0.02 & 0.05 & [88] \\
\hline France & Gironde estuary & 2001 & LR & ww & $4.20 \pm 0.50$ & & $0.10 \pm 0.01$ & & $<0.07$ & & [89] \\
\hline Italy & Adriatic Sea & 2003 & LA & ww & $6.59 \pm 1.14$ & $0.93 \pm 0.14$ & $0.04 \pm 0.02$ & $0.15 \pm 0.06$ & & $0.04 \pm 0.02$ & [84] \\
\hline Italy & Adriatic Sea & 2003 & LA & ww & & & 0.05 & & & & [84] \\
\hline Italy & Adriatic Sea & 2003 & CL & ww & $6.90 \pm 0.16$ & $0.84 \pm 0.17$ & $0.05 \pm 0.02$ & $0.16 \pm 0.05$ & & $0.04 \pm 0.02$ & [84] \\
\hline Italy & Ligurian Sea & 2008 & MC & ww & & & $<0.01$ & & 0.01 & 0.06 & [90] \\
\hline Italy & Caprolace lagoon & 2016 & CL & ww & $6.11 \pm 2.54$ & $0.34 \pm 0.20$ & $0.10 \pm 0.06$ & $0.00 \pm 0.01$ & $0.00 \pm 0.00$ & $0.00 \pm 0.01$ & Present study \\
\hline Italy & Fogliano lagoon & 2016 & CL & $\mathbf{w w}$ & $5.46 \pm 1.86$ & $0.73 \pm 1.01$ & $0.05 \pm 0.04$ & $0.00 \pm 0.01$ & $0.00 \pm 0.00$ & $0.00 \pm 0.00$ & Present study \\
\hline Tunisia & Ghar El Melh & 2004 & MC & $\mathrm{dw}$ & & & 0.34 & & 0.02 & 0.20 & [91] \\
\hline Tunisia & Sfax & 2014 & LA & ww & $45.26 \pm 0.81$ & & $0.12 \pm 0.02$ & & 0.100 .01 & $0.06 \pm 0.00$ & [92] \\
\hline Tunisia & Gulf of Gabes & 2015 & MC & $d w$ & $0.77 \pm 0.09$ & $6.276 \pm 3.845$ & & & & $5.21 \pm 1.43$ & [93] \\
\hline Egypt & El-Mex Bay & 2003 & MC & ww & 6.75 & 1.22 & & 0.21 & 0.47 & 0.73 & [94] \\
\hline Egypt & Manzala lake & $\mathrm{nr}$ & $\mathrm{MC}$ & $\mathrm{dw}$ & 32.42 & 4.62 & & & 1.94 & 3.15 & [31] \\
\hline Egypt & Manzala lake & $\mathrm{nr}$ & LR & $\mathrm{dw}$ & 31.05 & 5.36 & & & 1.07 & 2.65 & [31] \\
\hline Egypt & El Serv & $\mathrm{nr}$ & LR & $\mathrm{dw}$ & $23.47 \pm 6.23$ & $2.9 \pm 2.83$ & & & & $4.97 \pm 6.17$ & [95] \\
\hline Egypt & Manzala lake & $\mathrm{nr}$ & LR & $\mathrm{dw}$ & $16.62 \pm 3.02$ & $1.47 \pm 0.32$ & & & $0.05 \pm 0.1$ & $4.55 \pm 6.19$ & [95] \\
\hline Egypt & Med Sea & $\mathrm{nr}$ & LR & $\mathrm{dw}$ & $20.19 \pm 3.5$ & $2.13 \pm 1.02$ & & & $0.82 \pm 1.23$ & $9.39 \pm 10.06$ & [95] \\
\hline Turkey & Karatas & 2003 & MC & $d w$ & & 9.83 & & & 1.45 & 6.33 & [96] \\
\hline Turkey & Iskenderun Bay & 1999 & MC & ww & $47.25 \pm 18.77$ & $1.39 \pm 0.80$ & & $1.71 \pm 0.92$ & & $6.42 \pm 2.82$ & [97] \\
\hline Turkey & Camlik lagoon & 2001 & $\mathrm{MC}$ & $\mathrm{dw}$ & 88.9 & & & & 0.07 & & [98] \\
\hline Turkey & Camlik lagoon & 2015 & LA & ww & $4.92 \pm 0.35$ & $0.88 \pm 0.09$ & & $0.81 \pm 0.05$ & $0.64 \pm 0.06$ & $0.45 \pm 0.06$ & [99] \\
\hline Turkey & Camlik lagoon & 2015 & LS & ww & $4.21 \pm 0.31$ & $0.67 \pm 0.11$ & & $0.49 \pm 0.12$ & $0.36 \pm 0.05$ & $0.98 \pm 0.21$ & [99] \\
\hline Turkey & Camlik lagoon & 2015 & MC & ww & $6.13 \pm 0.57$ & $0.70 \pm 0.19$ & & $0.27 \pm 0.05$ & $0.13 \pm 0.02$ & $0.63 \pm 0.12$ & [99] \\
\hline Turkey & Tuzla lagoon & 2001 & MC & $\mathrm{dw}$ & 39.60 & 0.53 & & & 0.09 & 0.92 & [100] \\
\hline Turkey & Tuzla lagoon & 2015 & MC & ww & $21.20 \pm 7.08$ & $0.64 \pm 0.13$ & & $0.39 \pm 0.04$ & $0.18 \pm 0.02$ & $0.26 \pm 0.05$ & [99] \\
\hline Turkey & Tuzla lagoon & 2015 & LA & ww & $7.80 \pm 1.03$ & $1.14 \pm 0.12$ & & $1.05 \pm 0.17$ & $0.35 \pm 0.07$ & $0.37 \pm 0.04$ & [99] \\
\hline Turkey & Tuzla lagoon & 2015 & LS & ww & $15.00 \pm 2.61$ & $0.95 \pm 0.29$ & & $0.62 \pm 0.12$ & $0.06 \pm 0.01$ & $0.78 \pm 0.14$ & [99] \\
\hline
\end{tabular}




\section{Conclusions}

The results of the present study allow for some conclusive considerations. Contamination levels found in the thick-lipped mullet at both Caprolace and Fogliano lagoons were generally low, mostly in line or lower than levels recorded in mullets and other fish species in transitional habitats in the Mediterranean region. Based on the high number of contaminants and congeners examined, it has been possible nevertheless to highlight differences in contamination patterns between the two adjacent lagoons. These share a common geographical position, and have undergone similar changes in the surrounding landscape, in their hydro-morphology and in their management framework. The presence of persistent contaminants or their metabolites, some of which banned many years ago, testify long standing pollution, while others are more directly related to the current situation of each of the two lagoons. Differences found in some contaminants can be related to site-specific differences in the ecological conditions of the two lagoons, such as water management and their renewal, or to the different duration of the fish permanence in each lagoon, as ascertained by mullet age estimation.

The quality status of the two lagoons under study, evaluated taking into account anthropogenic pressures inside and around the water bodies, is good. This is attributable to the fact that anthropogenic pressures related to the lagoon resources exploitation (fisheries, aquaculture) are today reduced, owing to the present management of the lagoons under the National Park Authority, mainly focused on habitat and resource conservation. On the other hand, such a management framework does not address issues such as solving the structural problems of the lagoons first of all nor the maintenance of exchanges with the sea by the tidal channels. This is the crucial factor for the correct functionality of coastal lagoons, both hydrological (water renewal) and biological (fish recruitment). Occasional interventions, such as dredging, can have adverse effects, recirculating contaminants which then accumulate along trophic chains, and therefore posing threats to the lagoon living resources. Results of this study can therefore provide support to management choices in Mediterranean lagoon environments, especially those committed to the protection and conservation of biodiversity.

Supplementary Materials: The following are available online at http://www.mdpi.com/2073-4441/12/12/3450/s1. Methods of determination of persistent organic pollutants (POPs) and metals; Table S1: Results of analyses of variance (F statistic and level of significance p) carried out to test the effects of site and gender factors on biometric and biological features of thick-lipped mullet samples from Fogliano and Caprolace. Table S2: Results of analyses of variance (F statistic and level of significance $p$ ) carried out to test the effects of site and gender factors on contaminants on lw basis. Table S3: Results of analyses of variance (F statistic and level of significance p) carried out to test the effects of site and gender factors on contaminants on ww basis. Table S4: Medians, mean concentrations $( \pm \mathrm{SD})$ and ranges of organic compounds $\left(\mathrm{ng} \mathrm{g}^{-1} \mathrm{ww}\right)$ detected in C. labrosus muscle from Fogliano and Caprolace.

Author Contributions: Conceptualization, E.C., F.C. and C.L.; Methodology for quality status assessment, C.L, E.C. and L.T.; Methodology for contamination, A.C., G.M., G.P., C.M., M.F. and F.C.; software, F.C.; validation, F.C. and C.L.; formal analysis, G.M., G.P., M.C., F.C.; investigation, C.L.; data curation, C.L., L.T.; writing-original draft preparation, C.L. and F.C.; writing-review and editing, E.C., C.B., A.C.; supervision, E.C.; project administration, E.C. All authors have read and agreed to the published version of the manuscript.

Funding: This research was funded by Italian Ministry of Agricultural Food and Forestry Policy within the Research Project LAGURES (grant N. J88C13001250001).

Acknowledgments: The authors thank the Circeo National Park and the Ufficio Territoriale Carabinieri per la Biodiversità di Fogliano (UTCB) for their willingness to support the research. The authors also acknowledge the support of Massimo Cecchetti and Andrea Fusari during mullet sampling.

Conflicts of Interest: The authors declare no conflict of interest.

\section{References}

1. Yáñez-Arancibia, A.; Lara Domínguez, A.L.; Pauly, D. Coastal Lagoons as Fish Habitats. In Coastal Lagoon Processes; Kjerfve, K., Ed.; Elsevier: Amsterdam, The Netherlands, 1994; Volume 15, pp. 363-376.

2. Aliaume, C.; Do Chi, T.; Viaroli, P.; Zaldivar, J.M. Coastal lagoons of Southern Europe: Recent changes and future scenarios. Transit. Waters Monogr. 2007, 1, 1-12. [CrossRef] 
3. Pérez-Ruzafa, A.; Marcos, C.; Pérez-Ruzafa, I.M.; Pérez-Marcos, M. Coastal lagoons: "transitional ecosystems" between transitional and coastal waters. J. Coast. Conserv. 2011, 15, 369-392. [CrossRef]

4. Pérez-Ruzafa, A.; Marcos, C.; Pérez-Ruzafa, I.M. Mediterranean coastal lagoons in an ecosystem and aquatic resources management context. Phys. Chem. Earthparts A/B/C 2011, 36, 160-166. [CrossRef]

5. Pérez-Ruzafa, A.; Marcos, C. Fisheries in coastal lagoons: An assumed but poorly researched aspect of the ecology and functioning of coastal lagoons. Estuar. Coast. Shelf Sci. 2012, 110, 15-31. [CrossRef]

6. Kara, M.H.; Quignard, J.P. Fishes in Lagoons and Estuaries in the Mediterranean 1: Diversity, Bioecology and Exploitation; John Wiley \& Sons: Hoboken, NY, USA, 2018; p. 269.

7. Cataudella, S.; Massa, F.; Crosetti, D. Interactions between Aquaculture and Capture Fisheries: A Methodological Perspective; FAO: Rome, Italy, 2015; p. 236, ISBN 9251053782.

8. Costanza, R.; D’Arge, R.; de Groot, R.; Farber, S.; Grasso, M.; Hannon, B.; Limburg, K.; Naeem, S.; O’Neill, R.V.; Paruelo, J.; et al. The value of the world's ecosystem services and natural capital. Nature 1997, 387, 253-260. [CrossRef]

9. Barbier, E.B.; Hacker, S.D.; Kennedy, C.; Koch, E.W.; Stier, A.C.; Silliman, B.R. The value of estuarine and coastal ecosystem services. Ecol. Monogr. 2011, 81, 169-193. [CrossRef]

10. Newton, A.; Brito, A.C.; Icely, J.D.; Derolez, V.; Clara, I.; Angus, S.; Schernewski, G.; Inácio, M.; Lillebø, A.I.; Sousa, A.I.; et al. Assessing, quantifying and valuing the ecosystem services of coastal lagoons. J. Nat. Conserv. 2018, 44, 50-65. [CrossRef]

11. Velasco, A.M.; Pérez-Ruzafa, A.; Martínez-Paz, J.M.; Marcos, C. Ecosystem services and main environmental risks in a coastal lagoon (Mar Menor, Murcia, SE Spain): The public perception. J. Nat. Conserv. 2018, 43, 180-189. [CrossRef]

12. Elliott, M.; Burdon, D.; Atkins, J.P.; Borja, A.; Cormier, R.; de Jonge, V.N.; Turner, R.K. “And DPSIR begat DAPSI(W)R(M)!"-A unifying framework for marine environmental management. Mar. Pollut. Bull. 2017, 118, 27-40. [CrossRef]

13. Pérez-Ruzafa, A.; De Pascalis, F.; Ghezzo, M.; Quispe-Becerra, J.I.; Hernández-García, R.; Muñoz, I.; Vergara, C.; Pérez-Ruzafa, I.M.; Umgiesser, G.; Marcos, C. Connectivity between coastal lagoons and sea: Asymmetrical effects on assemblages' and populations' structure. Estuar. Coast. Shelf Sci. 2019, 216, 171-186. [CrossRef]

14. Newton, A.; Icely, J.; Cristina, S.; Brito, A.; Cardoso, A.C.; Colijn, F.; Riva, S.D.; Gertz, F.; Hansen, J.W.; Holmer, M.; et al. An overview of ecological status, vulnerability and future perspectives of European large shallow, semi-enclosed coastal systems, lagoons and transitional waters. Estuar. Coast. Shelf Sci. 2014, 140, 95-122. [CrossRef]

15. Katselis, G.; Moutopoulos, D.K.; Dimitriou, E.N.; Koutsikopoulos, C. Long-term changes of fisheries landings in enclosed gulf lagoons (Amvrakikos Gulf, W Greece): Influences of fishing and other human impacts. Estuar. Coast. Shelf Sci. 2013, 131, 31-40. [CrossRef]

16. Costanza, R.; Kubiszewski, I.; Ervin, D.; Bluffstone, R.; Boyd, J.; Brown, D.; Chang, H.; Dujon, V.; Granek, E.; Polasky, S.; et al. Valuing ecological systems and services. F1000 Biol. Rep. 2011, 3, 34-45. [CrossRef]

17. Chovanec, A.; Hofer, R.; Schiemer, F. Fish as bioindicators. In Trace Metals and other Contaminants in the Environment; Markert, B.A., Breure, A.M., Zechmeister, H.G., Eds.; Elsevier Science: Amsterdam, The Netherlands, 2003; Volume 6, pp. 639-676.

18. EU Water Framework Directive. Directive of the European parliament and of the council 2000/60/EC establishing a framework for community action in the field of water policy. Off. J. Eur. Communities 2000, 327, 1-73.

19. Pérez-Domínguez, R.; Maci, S.; Courrat, A.; Lepage, M.; Borja, A.; Uriarte, A.; Neto, J.M.; Cabral, H.; St.Raykov, V.; Franco, A.; et al. Current developments on fish-based indices to assess ecological-quality status of estuaries and lagoons. Ecol. Indic. 2012, 23, 34-45. [CrossRef]

20. Pérez-Domínguez, R.; Álvarez, M.C.; Borja, A.; Cabral, H.; Courrat, A.; Elliott, M.; Fonseca, V.; Franco, A.; Gamito, R.; Garmendia, J.; et al. Deliverable D4.4-5: Precision and behaviour of fish-based ecological quality metrics in relation to natural and anthropogenic pressure gradients in European estuaries and lagoons. Ph.D. Thesis, University of Hull, Hull, UK, 2012.

21. Pasquaud, S.; Courrat, A.; Fonseca, V.F.; Gamito, R.; Gonçalves, C.I.; Lobry, J.; Lepage, M.; Costa, M.J.; Cabral, H. Strength and time lag of relationships between human pressures and fish-based metrics used to assess ecological quality of estuarine systems. Estuar. Coast. Shelf Sci. 2013, 134, 119-127. [CrossRef] 
22. Souza, G.B.G.; Vianna, M. Fish-based indices for assessing ecological quality and biotic integrity in transitional waters: A systematic review. Ecol. Indic. 2020, 109, 105665. [CrossRef]

23. Uriarte, A.; Borja, A. Assessing fish quality status in transitional waters, within the European Water Framework Directive: Setting boundary classes and responding to anthropogenic pressures. Estuar. Coast. Shelf Sci. 2009, 82, 214-224. [CrossRef]

24. Teichert, N.; Borja, A.; Chust, G.; Uriarte, A.; Lepage, M. Restoring fish ecological quality in estuaries: Implication of interactive and cumulative effects among anthropogenic stressors. Sci. Total Environ. 2016, 542, 383-393. [CrossRef]

25. Cavraro, F.; Bettoso, N.; Zucchetta, M.; D'Aietti, A.; Faresi, L.; Franzoi, P. Body condition in fish as a tool to detect the effects of anthropogenic pressures in transitional waters. Aquat. Ecol. 2019, 53, 21-35. [CrossRef]

26. Belpaire, C.; Goemans, G. The European Eel Anguilla anguilla, a rapporteur of the chemical status for the water framework directive? Vie et Milieu 2007, 57, 235-252.

27. Van Ael, E.; Belpaire, C.; Breine, J.; Geeraerts, C.; Van Thuyne, G.; Eulaers, I.; Blust, R.; Bervoets, L. Are persistent organic pollutants and metals in eel muscle predictive for the ecological water quality? Environ. Pollut. 2014, 186, 165-171. [CrossRef] [PubMed]

28. Tancioni, L.; Caprioli, R.; Dawood Al-Khafaji, A.H.; Mancini, L.; Boglione, C.; Ciccotti, E.; Cataudella, S. Anthropogenic threats to fish of interest in aquaculture: Gonad intersex in a wild population of thicklip grey mullet Liza ramada (Risso, 1827) from a polluted estuary in central Italy. Aquac. Res. 2016, 47, 1670-1674. [CrossRef]

29. Facca, C.; Cavraro, F.; Franzoi, P.; Malavasi, S. Lagoon Resident Fish Species of Conservation Interest According to the Habitat Directive (92/43/CEE): A Review on Their Potential Use as Ecological Indicator Species. Water 2020, 12, 2059. [CrossRef]

30. Marcovecchio, J. The use of Micropogonias furnieri and Mugil liza as bioindicators of heavy metals pollution in La Plata river estuary, Argentina. Sci. Total Environ. 2004, 323, 219-226. [CrossRef]

31. Bahnasawy, M.; Khidr, A.A.; Dheina, N. Seasonal variations of heavy metals concentrations in Mullet, Mugil cephalus and Liza ramada (Mugilidae) from Lake Manzala, Egypt. J. Appl. Sci. Res. 2009, 5, 845-852. [CrossRef]

32. Whitfield, A.K.; Panfili, J.; Durand, J.D. A global review of the cosmopolitan flathead mullet Mugil cephalus Linnaeus 1758 (Teleostei: Mugilidae), with emphasis on the biology, genetics, ecology and fisheries aspects of this apparent species complex. Rev. Fish Biol. Fish. 2012, 22, 641-681. [CrossRef]

33. Waltham, N.J.; Teasdale, P.R.; Connolly, R.M. Use of flathead mullet (Mugil cephalus) in coastal biomonitor studies: Review and recommendations for future studies. Mar. Pollut. Bull. 2013, 69, 195-205. [CrossRef]

34. Crosetti, D.; Blaber, S.J. Biology, Ecology and Culture of Grey Mullets (Mugilidae); CRC Press: Boca Raton, FL, USA, 2015; p. 539.

35. Kara, M.H.; Quignard, J. Fishes in Lagoons and Estuaries in the Mediterranean 3A; John Wiley \& Sons: Hoboken, NY, USA, 2019; p. 326.

36. Cioffi, F.; Gallerano, F. Management strategies for the control of eutrophication processes in Fogliano lagoon (Italy): A long-term analysis using a mathematical model. Appl. Math. Model. 2001, 25, 385-426. [CrossRef]

37. Cataldo, S.; Copiz, R.; Lorito, A.; Magaudda, S.; Parente, S.; Perotto, C.; Valle, N. REWETLAND. Widespread introduction of constructed wetlands for a wastewater treatment of Agro Pontino; "Le Scienze"; Edizioni Belvedere: Latina, Italy, 2014; p. 176.

38. Lein, J. An expert system approach to environmental impact assessment. Int. J. Environ. Stud. 1989, 33, 13-27. [CrossRef]

39. Capoccioni, F.; Leone, C.; Belpaire, C.; Malarvannan, G.; Poma, G.; De Matteis, G.; Tancioni, L.; Contò, M.; Failla, S.; Covaci, A.; et al. Quality assessment of escaping silver eel (Anguilla anguilla L.) to support management and conservation strategies in Mediterranean coastal lagoons. Environ. Monit. Assess. 2020, 192, 570. [CrossRef]

40. Hile, R.; Jobes, F.W. Age, Growth, and Production of the Yellow Perch, Perca Flavescens (Mitchill), of Saginaw Bay. Trans. Am. Fish. Soc. 1941, 70, 102-122. [CrossRef]

41. Lin, Y.-J.; Tzeng, W.-N. Validation of annulus in otolith and estimation of growth rate for Japanese eel Anguilla japonica in tropical southern Taiwan. Environ. Biol. Fishes 2009, 84, 79-87. [CrossRef]

42. Le Cren, E.D. The Length-Weight Relationship and Seasonal Cycle in Gonad Weight and Condition in the Perch (Perca fluviatilis). J. Anim. Ecol. 1951, 20, 201. [CrossRef] 
43. Van Der Oost, R.; Goksøyr, A.; Celander, M.; Heida, H.; Vermeulen, N.P.E. Biomonitoring of aquatic pollution with feral eel (Anguilla anguilla). II. Biomarkers: Pollution-induced responses. Aquat. Toxicol. 1996, 36, 189-222. [CrossRef]

44. ARPA Lazio. Stato Ecologico e Stato Chimico dei Corpi Idrici di Transizione Periodo di monitoraggio 2015-2017 ai sensi del DM 260/2010 e Dlgs 172/2015. 2017; p. 3. Available online: http://www.arpalazio.gov.it/ ambiente/acqua/doc/Sintesi\%20Stato\%20Ecologico\%20e\%20Chimico\%20-\%20Transizione.pdf (accessed on 10 November 2020).

45. European Parliament and Council. EU Directive of 12 August 2013 amending Directives 2000/60/EC and 2008/105/EC as regards priority substances in the field of water policy. Off. J. Eur. Communities 2013.

46. Italian Government. Attuazione della direttiva 2013/39/UE, che modifica le direttive 2000/60/CE per quanto riguarda le sostanze prioritarie nel settore della politica delle acque. Gazz. Uff. 2015, 250.

47. Belpaire, C.; Geeraerts, C.; Roosens, L.; Neels, H.; Covaci, A. What can we learn from monitoring PCBs in the European eel? A Belgian experience. Environ. Int. 2011, 37, 354-364. [CrossRef]

48. Malarvannan, G.; Belpaire, C.; Geeraerts, C.; Eulaers, I.; Neels, H.; Covaci, A. Assessment of persistent brominated and chlorinated organic contaminants in the European eel (Anguilla anguilla) in Flanders, Belgium: Levels, profiles and health risk. Sci. Total Environ. 2014, 482-483, 222-233. [CrossRef]

49. Storelli, M.M.; Barone, G.; Garofalo, R.; Marcotrigiano, G.O. Metals and organochlorine compounds in eel (Anguilla anguilla) from the Lesina lagoon, Adriatic Sea (Italy). Food Chem. 2007, 100, 1337-1341. [CrossRef]

50. Ferrante, M.C.; Clausi, M.T.; Meli, R.; Fusco, G.; Naccari, C.; Lucisano, A. Polychlorinated biphenyls and organochlorine pesticides in European eel (Anguilla anguilla) from the Garigliano River (Campania region, Italy). Chemosphere 2010, 78, 709-716. [CrossRef] [PubMed]

51. Casini, S.; Aurigi, S.; Fossi, M.C.; Monaci, F.; Focardi, S. Evaluation of Environmental Quality for the Management of Brackish Wetlands: Use of Bioindicators and Biomarkers in the Pontine Lakes. In Mediterranean Ecosystems; Springer: Milano, Italy, 2001; pp. 65-70.

52. Bettinetti, R.; Quadroni, S.; Boggio, E.; Galassi, S. Recent DDT and PCB contamination in the sediment and biota of the Como Bay (Lake Como, Italy). Sci. Total Environ. 2016. [CrossRef] [PubMed]

53. Jürgens, M.D.; Crosse, J.; Hamilton, P.B.; Johnson, A.C.; Jones, K.C. The long shadow of our chemical past High DDT concentrations in fish near a former agrochemicals factory in England. Chemosphere 2016, 162, 333-344. [CrossRef] [PubMed]

54. Ameur, W.B.; Trabelsi, S.; El Megdiche, Y.; Ben Hassine, S.; Barhoumi, B.; Hammami, B.; Eljarrat, E.; Barceló, D.; Driss, M.R. Concentration of polychlorinated biphenyls and organochlorine pesticides in mullet (Mugil cephalus) and sea bass (Dicentrarchus labrax) from Bizerte Lagoon (Northern Tunisia). Chemosphere 2013, 90, 2372-2380. [CrossRef] [PubMed]

55. Renzi, M.; Specchiulli, A.; Baroni, D.; Scirocco, T.; Cilenti, L.; Focardi, S.; Breber, P.; Focardi, S. Trace elements in sediments and bioaccumulation in European silver eels (Anguilla anguilla L.) from a Mediterranean lagoon (SE Italy). Int. J. Environ. Anal. Chem. 2012, 92, 676-697. [CrossRef]

56. Naso, B.; Perrone, D.; Ferrante, M.C.; Bilancione, M.; Lucisano, A. Persistent organic pollutants in edible marine species from the Gulf of Naples, Southern Italy. Sci. Total Environ. 2005. [CrossRef] [PubMed]

57. Jürgens, M.D.; Johnson, A.C.; Jones, K.C.; Hughes, D.; Lawlor, A.J. The presence of EU priority substances mercury, hexachlorobenzene, hexachlorobutadiene and PBDEs in wild fish from four English rivers. Sci. Total Environ. 2013, 461-462, 441-452. [CrossRef]

58. Eljarrat, E.; Barceló, D. How do measured PBDE and HCBD levels in river fish compare to the European Environmental Quality Standards? Environ. Res. 2018, 160, 203-211. [CrossRef]

59. Burreau, S.; Zebühr, Y.; Broman, D.; Ishaq, R. Biomagnification of PBDEs and PCBs in food webs from the Baltic Sea and the northern Atlantic Ocean. Sci. Total Environ. 2006, 366, 659-672. [CrossRef]

60. Piersanti, A.; Tavoloni, T.; Bastari, E.; Lestingi, C.; Romanelli, S.; Rossi, R.; Saluti, G.; Moretti, S.; Galarini, R. A GC-EI-MS/MS Method for the Determination of 15 Polybrominated Diphenyl Ethers (PBDEs) in Fish and Shellfish Tissues. Food Anal. Methods 2018, 11, 355-366. [CrossRef]

61. El Megdiche, Y.; Ameur, W.B.; Bèchir, H.; Hassine, S.B.; Badreddine, B.; Touil, S.; Driss, M.R.; Eljarrat, E.; Barceló, D. Anthropogenic (PBDE) and naturally-produced (MeO-PBDE) brominated compound levels in Bizerte Lagoon clams (Ruditapes decussatus): Levels and human health risk assessment. Mar. Pollut. Bull. 2017, 125, 176-185. [CrossRef] [PubMed] 
62. Ben Ameur, W.; Ben Hassine, S.; Eljarrat, E.; El Megdiche, Y.; Trabelsi, S.; Hammami, B.; Barceló, D.; Driss, M.R. Polybrominated diphenyl ethers and their methoxylated analogs in mullet (Mugil cephalus) and sea bass (Dicentrarchus labrax) from Bizerte Lagoon, Tunisia. Mar. Environ. Res. 2011, 72, 258-264. [CrossRef] [PubMed]

63. Voorspoels, S.; Covaci, A.; Schepens, P. Polybrominated diphenyl ethers in marine species from the Belgian North Sea and the Western Scheldt Estuary: Levels, profiles, and distribution. Environ. Sci. Technol. 2003, 37, 4348-4357. [CrossRef] [PubMed]

64. Gribble, G.W. The natural production of organobromine compounds. Environ. Sci. Pollut. Res. 2000, 7, 37-49. [CrossRef] [PubMed]

65. Faulkner, D.J. Marine natural products. Nat. Prod. Rep. 2001, 18, 1-49. [CrossRef] [PubMed]

66. Mekni, S.; Barhoumi, B.; Aznar-Alemany, Ò.; Touil, S.; Driss, M.R.; Barceló, D.; Eljarrat, E. Occurrence of halogenated flame retardants in sediments and sea urchins (Paracentrotus lividus) from a North African Mediterranean coastal lagoon (Bizerte, Tunisia). Sci. Total Environ. 2019, 654, 1316-1325. [CrossRef]

67. Löfstrand, K.; Liu, X.; Lindqvist, D.; Jensen, S.; Asplund, L. Seasonal variations of hydroxylated and methoxylated brominated diphenyl ethers in blue mussels from the Baltic Sea. Chemosphere 2011, 84, 527-532. [CrossRef]

68. Pastor, D.; Boix, J.; Fernández, V.; Albaigés, J. Bioaccumulation of organochlorinated contaminants in three estuarine fish species (Mullus barbatus, Mugil cephalus and Dicentrarcus labrax). Mar. Pollut. Bull. 1996, 32, 257-262. [CrossRef]

69. Coelhan, M.; Strohmeier, J.; Barlas, H. Organochlorine levels in edible fish from the Marmara Sea, Turkey. Environ. Int. 2006, 32, 775-780. [CrossRef]

70. Hitch, R.K.; Day, H.R. Unusual persistence of DDT in some Western USA soils. Bull. Environ. Contam. Toxicol. 1992, 48, 259-264. [CrossRef]

71. Zhou, R.; Zhu, L.; Chen, Y.; Kong, Q. Concentrations and characteristics of organochlorine pesticides in aquatic biota from Qiantang River in China. Environ. Pollut. 2008, 151, 190-199. [CrossRef]

72. Curtis, C.F. Should the use of DDT be revived for malaria vector control? Biomedica 2002, 22, $455-461$. [CrossRef]

73. Pombi, M.; Modiano, D.; Corbellini, G. Malaria Eradication in Italy: The Story of a First Success; Oxford University Press: Oxford, UK, 2018; pp. 200-2016.

74. Quadroni, S.; Galassi, S.; Capoccioni, F.; Ciccotti, E.; Grandi, G.; De Leo, G.A.; Bettinetti, R. Contamination, parasitism and condition of Anguilla anguilla in three Italian stocks. Ecotoxicol. 2013, 22, 94-108. [CrossRef]

75. Ramalhosa, E.; Monterroso, P.; Abreu, S.; Pereira, E.; Vale, C.; Duarte, A. Storage and export of mercury from a contaminated bay (Ria de Aveiro, Portugal). Wetl. Ecol. Manag. 2001, 9, 311-316. [CrossRef]

76. Ramalhosa, E.; Pereira, E.; Vale, C.; Válega, M.; Duarte, A.C. Distribution of mercury in the upper sediments from a polluted area (Ria de aveiro, Portugal). Mar. Pollut. Bull. 2005, 50, 682-686. [CrossRef]

77. Jezierska, B.; Witeska, M. The metal uptake and accumulation in fish living in polluted waters. In Soil and Water Pollution Monitoring, Protection and Remediation; Springer: Dordrecht, The Netherlands, 2007; pp. 107-114.

78. Ferreira, M.; Antunes, P.; Gil, O.; Vale, C.; Reis-Henriques, M.A. Organochlorine contaminants in flounder (Platichthys flesus) and mullet (Mugil cephalus) from Douro estuary, and their use as sentinel species for environmental monitoring. Aquat. Toxicol. 2004, 69, 347-357. [CrossRef]

79. Baptista, J.; Pato, P.; Tavares, S.; Duarte, A.C.; Pardal, M.A. PCB bioaccumulation in three mullet species-A comparison study. Ecotoxicol. Environ. Saf. 2013, 94, 147-152. [CrossRef]

80. Bodin, N.; Tapie, N.; Le Ménach, K.; Chassot, E.; Elie, P.; Rochard, E.; Budzinski, H. PCB contamination in fish community from the Gironde estuary (France): Blast from the past. Chemosphere 2014, 98, 66-72. [CrossRef]

81. Bocquené, G.; Abarnou, A. Organochlorinated pesticides, PCBs, dioxins, and PBDEs in grey mullets (Liza ramada) and allis shads (Alosa alosa) from the Vilaine estuary (France). Environ. Sci. Pollut. Res. 2013, 20, 667-675. [CrossRef]

82. Roche, H.; Vollaire, Y.; Persic, A.; Buet, A.; Oliveira-Ribeiro, C.; Coulet, E.; Banas, D.; Ramade, F. Organochlorines in the Vaccarès Lagoon trophic web (Biosphere Reserve of Camargue, France). Environ. Pollut. 2009, 157, 2493-2506. [CrossRef]

83. Garritano, S.; Pinto, B.; Calderisi, M.; Cirillo, T.; Amodio-Cocchieri, R.; Reali, D. Estrogen-like activity of seafood related to environmental chemical contaminants. Environ. Health 2006, 5. [CrossRef] [PubMed] 
84. Storelli, M.M.; Barone, G.; Storelli, A.; Marcotrigiano, G.O. Trace metals in tissues of mugilids (Mugil auratus, Mugil capito, and Mugil labrosus) from the Mediterranean Sea. Bull. Environ. Contam. Toxicol. 2006, 77, 43-50. [CrossRef] [PubMed]

85. Masmoudi, W.; Romdhane, M.S.; Khériji, S.; El Cafsi, M. Polychlorinated biphenyl residues in the golden grey mullet (Liza aurata) from Tunis Bay, Mediterranean sea (Tunisia). Food Chem. 2007, 105, 72-76. [CrossRef]

86. França, S.; Vinagre, C.; Caçador, I.; Cabral, H.N. Heavy metal concentrations in sediment, benthic invertebrates and fish in three salt marsh areas subjected to different pollution loads in the Tagus Estuary (Portugal). Mar. Pollut. Bull. 2005, 50, 998-1003. [CrossRef] [PubMed]

87. Blasco, J.; Arias, A.M.; Sáenz, V. Heavy metals in organisms of the River Guadalquivir estuary: Possible incidence of the Aznalcollar disaster. Sci. Total Environ. 1999, 242, 249-259. [CrossRef]

88. Usero, J.; Izquierdo, C.; Morillo, J.; Gracia, I. Heavy metals in fish (Solea vulgaris, Anguilla anguilla and Liza aurata) from salt marshes on the southern Atlantic coast of Spain. Environ. Int. 2004, 29, 949-956. [CrossRef]

89. Durrieu, G.; Maury-Brachet, R.; Girardin, M.; Rochard, E.; Boudou, A. Contamination by heavy metals $(\mathrm{Cd}, \mathrm{Zn}, \mathrm{Cu}$, and $\mathrm{Hg}$ ) of eight fish species in the Gironde estuary (France). Estuaries 2005, 28, 581-591. [CrossRef]

90. Squadrone, S.; Prearo, M.; Gavinelli, S.; Pellegrino, M.; Tarasco, R.; Benedetto, A.; Abete, M.C. Heavy metals in Mugil cephalus (Mugilidae) from the Ligurian Sea (North-West Mediterranean, Italy). Food Addit. Contam. Part B Surveill. 2013, 6, 134-138. [CrossRef]

91. Chouba, L.; Kraiem, M.; Njimi, W.; Tissaoui, C.H.; Thompson, J.R.; Flower, R.J. Seasonal variation of heavy metals ( $\mathrm{Cd}, \mathrm{Pb}$ and $\mathrm{Hg}$ ) in sediments and in mullet, Mugil cephalus (Mugilidae), from the Ghar el Melh lagoon (Tunisia). Transit. Waters Bull. 2007, 1, 45-52. [CrossRef]

92. Zohra, B.S.; Habib, A. Assessment of heavy metal contamination levels and toxicity in sediments and fishes from the Mediterranean Sea (southern coast of Sfax, Tunisia). Environ. Sci. Pollut. Res. 2016, 23, 13954-13963. [CrossRef]

93. Annabi, A.; El Mouadeb, R.; Herrel, A. Distinctive accumulation patterns of heavy metals in Sardinella aurita (Clupeidae) and Mugil cephalus (Mugilidae) tissues. Environ. Sci. Pollut. Res. 2018, 25, 2623-2629. [CrossRef]

94. Khaled, A. Heavy metals concentrations in certain tissues of five commercially important fishes from El-Mex Bay, Alexandria, Egypt. Egypt. J. Aquat. Biol. Fish. 2004, 8, 51-64.

95. Beheary, M.S.; El-Matary, F.A. Bioaccumulation of Heavy Metals and Implications Associated with Consumption of the Thinlip Mullet (Liza ramada) Collected from Sites of Varying Salinity. Asian J. Fish. Aquat. Res. 2018, 1-15. [CrossRef]

96. Çoğun, H.Y.; Yüzereroğlu, T.A.; Firat, Ö.; Gök, G.; Kargin, F. Metal concentrations in fish species from the Northeast Mediterranean Sea. Environ. Monit. Assess. 2006, 121, 429-436. [CrossRef]

97. Yilmaz, A.B. Levels of heavy metals ( $\mathrm{Fe}, \mathrm{Cu}, \mathrm{Ni}, \mathrm{Cr}, \mathrm{Pb}$, and $\mathrm{Zn}$ ) in tissue of Mugil cephalus and Trachurus mediterraneus from Iskenderun Bay, Turkey. Environ. Res. 2003, 92, 277-281. [CrossRef]

98. Dural, M.; Lugal Göksu, M.Z.; Özak, A.A.; Derici, B. Bioaccumulation of some heavy metals in different tissues of Dicentrarchus labrax L, 1758, Sparus aurata L, 1758 and Mugil cephalus L, 1758 from the Çamlik lagoon of the eastern cost of Mediterranean (Turkey). Environ. Monit. Assess. 2006, 118, 65-74. [CrossRef]

99. Tepe, Y.; Türkmen, A.; Türkmen, M. Comparison of heavy metal accumulation in tissues of economically valuable fish species from two nearby lagoons in Mediterranean coastal area. Indian J. Geo-Mar. Sci. 2017, 46, 1333-1338.

100. Dural, M.; Göksu, M.Z.L.; Özak, A.A. Investigation of heavy metal levels in economically important fish species captured from the Tuzla lagoon. Food Chem. 2007, 102, 415-421. [CrossRef]

Publisher's Note: MDPI stays neutral with regard to jurisdictional claims in published maps and institutional affiliations. 